\title{
Rethinking the Fair Cross-Section Requirement
}

\author{
Mitchell S. Zuklie†
}

By practical necessity, juries cannot replicate fully the diversity of the communities from which they are drawn. At a minimum, however, the Sixth Amendment requires juries to be drawn from a "representative cross section of the community." The Supreme Court has held that the underrepresentation of a particular group in a federal district jury pool is cognizable only when the group is a "distinctive" segment of the population. This Comment critiques the test used in federal courts to determine whether a particular group is distinctive. The author argues that Critical Legal Scholars have discredited many of the assumptions that underlie the existing doctrine, and that scholars and jurists need to rethink the fair cross-section requirement, especially with respect to the inclusion of the poor in jury venires. The author suggests that identifiable groups should be considered distinctive when judicial recognition of the group protects against the arbitrary exercise of prosecutorial authority, preserves public confidence in the fairness of criminal proceedings, and promotes shared civic responsibility for the administration of justice.

\section{INTRODUCTION}

The Sixth Amendment to the United States Constitution guarantees each criminal defendant the right to a trial "by an impartial jury." The Supreme Court has held that an "impartial jury" is one drawn from "a representative cross section of the community."2 The Supreme Court has invoked its supervisory power over federal courts to enforce the crosssection guarantee. ${ }^{3}$ In addition, the cross-section requirement applies to the

Copyright () 1996 California Law Review, Inc.

$\dagger$ A.B. Bowdoin College, 1991; J.D. candidate 1996, University of California, Berkeley (Boalt Hall). I am grateful to Marge Shultz, an outstanding educator and mentor, for her help, guidance, and friendship. Thanks also to Steve Bundy, Steve Raspe, and the selfless editors of the California Law Review, especially Maria Shanle, Scott Morgan, JoAn Cho, Teresa Renaker, Laura Diamond, Ellen Kaye Fleishhacker, Jackie Piscitello, and Karen Fass. Remaining mistakes or omissions are entirely my own. I am also grateful for the love and encouragement of my parents, my grandparents, George and Susan Varian, and Walter McGuinness. This Comment is dedicated to Holly, whose integrity, compassion, and patience are unfailing.

1. U.S. CoNST. amend. VI.

2. Taylor v. Louisiana, 419 U.S. 522,528 (1975).

3. See Thiel v. Southern Pac. Co., 328 U.S. 217, 225 (1940) (prohibiting discriminatory action by jury officials pursuant to the Supreme Court's supervisory power over federal courts); see also 
states, as a matter of fundamental right, through the Due Process Clause of the Fourteenth Amendment. ${ }^{4}$

In 1968, Congress enacted the Jury Selection and Service Act ("JSSA"). The JSSA codifies a crimmal defendant's constitutional right to a jury "selected at random from a fair cross section of the community." In addition, the JSSA extends the fair cross-section privilege to some civil litigants in federal court. ${ }^{7}$ To secure these rights, the JSSA requires each federal court to devise and implement "a written plan for random selection of grand and petit jurors" from a fair cross section of the community where the court convenes. ${ }^{8}$ Federal courts may draw the names of prospective jurors from either voter registration lists or the hists of actual voters within the district. ${ }^{9}$ However, the JSSA mandates that each federal district court "shall prescribe some other source or sources of names [of prospective jurors] im addition to voter lists where necessary" to ensure that, regardless of the representativeness of voter registration lists, the court will draw its jurors from a fair cross section of the community. ${ }^{10}$

Given their limited size, juries cannot fully replicate the diversity of the communities from which they are drawn. The Supreme Court has held that the underrepresentation of a particular group in jury venires is not judicially cognizable unless the underrepresented group is a "distinctive" segment of the population. ${ }^{11}$ This distinctiveness test seeks to distinguish groups vital to the legitimacy of the jury from among the "literally thousands of "cognizable groups" " present in society. ${ }^{12}$ The methodology for assessing a group's distinctiveness is well-developed. Courts generally consider whether members of the group share: (1) an attribute that defines and limits the group; (2) a common attitude, idea, or experience that distinguishes the group from other segments of society; and (3) a "community of interest" that the jury pool would not adequately reflect if it excluded members of the group. ${ }^{13}$

Donald H. Zeigler, Young Adults As a Cognizable Group in Jury Selection, 76 MicH. L. Rev. 1045, 1049-57 (1978) (detailing the judicial history of the fair cross-section doctrine); infra notes 44-52, 60-68 and accompanying text.

4. Duncan v. Louisiana, 391 U.S. 145,149 (1968). Since 1968, the cross-section requirement has applied with equal force to criminal cases in state and federal court. This Comment will focus on the application of the doctrine in federal courts.

5. 28 U.S.C. $\S \S 1861-1869$ (1988 \& Supp. 1994).

6. 28 U.S.C. $\S 1861$.

7. Section 1861 extends the fair cross-section guarantce to "all litigants in Federal courts entitled to trial by jury." 28 U.S.C. $\S 1861$ (emphasis added). This extension of the guarantee includes some civil litigants. See U.S. CoNsT. amend. VII (providing that "[i]n Suits at common law, ... the right of trial by jury shall be preserved').
8. 28 U.S.C $\S 1863$ (a).
9. 28 U.S.C. $\S 1863(\mathrm{~b})(2)$.
10. Id.
11. Duren v. Missouri, 439 U.S. 357, 364 (1979).
12. Anaya v. Hansen, 781 F.2d 1, 6 (1st Cir. 1986).
13. See infra note 126 . 
One might suspect that these broad doctrinal inquiries would produce significant rhetorical, social, and legal disagreenent. For example, do Vietnam war veterans share a unique community of interest not adequately represented by other groups? What about Asian Americans? Octogenarians? Electrical engineers? Despite the seeming difficulty of these queries, courts have been remarkably consistent in identifying which groups are and are not distinctive. For example, courts uniformly hold that women and African Americans are distinctive groups, while the poor are not. ${ }^{14}$ What accounts for this result?

This Comment argues that the current test for distinctiveness fails to provide courts with meaningful guidance and ultimately fails to advance the purposes of the fair cross-section doctrine - to protect against the arbitrary use of prosecutorial authority, to preserve public confidence in the fairness of the criminal justice system, and to promote shared civic responsibility for the administration of justice. ${ }^{15}$ It appears that courts lack a clear understanding of what the distinctiveness test aims to accomplish, and that they have collapsed their analysis of group distinctiveness into a single inquiry-whether meinbers of the group are victims of general societal discrimination. ${ }^{16}$ I argue that this inquiry should not be relevant to determining whether the composition of a jury pool has abridged a criminal defendant's Sixth Amendinent rights.

A description of iny methodology is in order. This Comment examines the federal courts' refusal to recognize the distinctiveness of the poor as a lens for evaluating the distinctiveness requirement in general. Several other cominentators have argued that adequate representation of the poor on jury venires is critical to fulfilling the fair cross-section guarantee. ${ }^{17}$ Most of the existing scholarship concerning the distinctiveness of the poor is grounded on the legislative history of the JSSA or the Sixth Amendinent. The goal of this Comment is inore modest. I attempt to reexamine a familiar question and to shed light on the existing literature, by drawing from the rich contributions of Critical Legal Studies. I start with the proposition that federal jury venires underrepresent the poor, ${ }^{18}$ and conclude that one cannot

14. See infra Part II.E.

15. See infra text accompanying notes 254-255.

16. See infra Part III.D.

17. The work of Laura Handman, Toni Massaro, and Darryl Brown, discussed infra, are particularly insightful.

18. See, e.g., Hayward R. Alker, Jr. et al., Jury Selection as a Biased Social Process, 11 LAw \& Soc'Y REv. 9, 38 (1976) (reporting that jury selection in the United States District Court for the District of Massachusetts led to the underrepresentation of both "the lower and upper socioeconomic classes"); Edward N. Beiser, Are Juries Representative?, 57 Judicature 194, $197-98$ (1973) (reporting that Rhode Island jury venires underrepresent persons outside the labor foree); Laura R. Handman, Underrepresentation of Economic Groups on Federal Juries, 57 B.U. L. REv. 198, 198 (1977) (stating that "low income persons are not present on federal juries in proportion to their numbers") (citations omitted); David Kairys et al., Jury Representativeness: A Mandate for Multiple Source Lists, 65 CALif. L. REv. 776, 805-07 (1977) (stating that federal jury source lists underrepresent the poor); Lyle Knowles \& Kenneth Hickman, Selecting a Jury of Peers: How Close Do We Get?, 12(2) J. PoLICE SCr. 
draw a principled distinction between the poor and groups that have been held distinctive for jury selection purposes. For this reason I argue that the federal courts need to rethink the fair cross-section doctrine and the distinctiveness requirement.

Part I of this Comment provides a brief overview of the jury selection process in federal court. Part II surveys the relevant case law, briefly describing the development of the fair cross-section doctrine, explaining its present scope, and examining why courts have declimed to recognize the poor as a distinctive group. Part III critiques the current method for determining distinctiveness, using the legal treatinent of the poor as an example, and argues that the test lacks fairness and predictive value. Part IV suggests an alternative test for distinctiveness based on whether judicial recognition of the group advances the purposes of the fair cross-section doctrine. Part $\mathrm{V}$ considers the practical difficulties associated with recognition of poor persons as a distinctive group and offers some potential solutions.

\section{The Jury Selection Process in Federal Courts}

This Part briefly describes the federal jury selection process. ${ }^{19}$ The first stage in federal jury selection is defining the geographic area from which to draw potential jurors. In federal court the relevant geographic area is the judicial district. The JSSA provides that federal courts may excuse from service people who live a great distance from the court, either in miles or in travel time. ${ }^{20}$

Second, the court must compile a list of the potential jurors within the district. The JSSA provides that federal districts may select the names of potential jurors from lists of registered or actual voters. ${ }^{21}$ However, voter lists typically underrepresent racial and ethnic mimorities and low-income

\& ADMTN. 207, 211 (1984) (reporting that in 1981 people with annual incomes of $\$ 10,000$ or below "were very seriously underrepresented on jury panels, and that higher incomes were overrepresented" in the County of Los Angeles); Cynthia A. Williams, Jury Source Representativeness and the Use of Voter Registration Lists, 65 N.Y.U. L. REv. 590, 614-15 (1990) (reporting that federal jury source lists underrepresent low-income persons by approximately 20\%); Darryl K. Brown, The Means and Ends of Representative Juries, 1 VA. J. Soc. PoL'y \& L. 445, 446 (1994) (book review) (stating that federal jury pools are underrepresentative in terms of race, ethnicity, age, and income level).

19. The organization of this Part follows the eight-step model describing jury selection developed by Professors Hiroshi Fukurai, Edgar Butler, and Richard Krooth. Hiroshr FUKURAI ET AL., RACE AND the Jury: Racial Disenfranchisement and the Search for Justice 40-41 (1993) [heteinafter FUKURAI]. For a more thorough examination of this model, see id. at 42-75.

20. 28 U.S.C. $\$ 1869(j)$. Professors Fukurai, Butler, and Krooth note that the distance exemption "often discriminates against those who hive in rural areas." FuKuRAl, supra note 19, at 44. For example, in San Bernardino County, Cahfornia, "residents in the large portion of the Mojave Desert and areas close to the state of Nevada-namely, Hispanics and native Americans-are automatically excluded from serving on juries" by virtue of the distance exemption. Id.

21. 28 U.S.C. $\S 1863(b)(2)$. 
persons. ${ }^{22}$ Therefore, each district court must also "prescribe some other source or sources of names in addition to voter lists where necessary to foster the policy" of the Act and to protect the right to a jury drawn from a fair cross-section of the community. ${ }^{23}$ For example, the statute expressly provides that the District of Colunibia may use the city telephone directory, rather than voter lists, as the source list for potential jurors. ${ }^{24}$ Each district's jury selection plan is subject to review and approval by a panel consisting of the chief judge of the district and the members of the judicial council of the circuit in which the district is located. ${ }^{25}$

Third, the court must compile a "master jury wheel" or "master file" of potential jurors. The JSSA requires each federal district court to select randomly a "master jury wheel" consisting of "at least one-half of [one] per centum" of the persons on the source list. ${ }^{26}$ The Act specifies that courts must update their jury wheels at least once every four years. ${ }^{27}$ Professors Fukurai, Butler, and Krooth have shown that racial minorities, as a group, are nore geographically inobile than nonminorities; therefore, infrequent updating of jury wheels tends to diminish the representativeness of a wheel drawn from a voter registration list. ${ }^{28}$

Fourth, the court creates a list of potential jurors who are qualified for service. To compile and update this list, district court officials "publicly draw at random from the master jury wheel the names of as many persons as inay be required for jury service." 29 The court then mails to each person selected a questionnaire designed to determme whether she is disqualified, ${ }^{30}$ exempt, ${ }^{31}$ or excused from jury service. ${ }^{32}$ The list of qualified

22. FUKURAI, supra note 19 , at 45 (reporting that "[r]esearch estimates that voter lists automatically exclude approximately one third of the adult population, tipping prospective jury selection toward the elderly, the relatively affluent, and the self-employed and government workers") (citations omitted); see also supra note 18.

23. 28 U.S.C. $\S 1863(b)(2)$.

24. Id.

25. 28 U.S.C. $\$ 1863(a)$.

26. 28 U.S.C. $\S 1863(b)(4)$.

27. Id.

28. FuKuraI, supra note 19 , at 48 .

29. 28 U.S.C. $\$ 1864(\mathrm{a})$.

30. The JSSA lists the following qualifications for federal jury service: (1) being "a citizen of the United States eighteen years old who has resided for a period of one year within the judicial district"; (2) having the ability "to read, write, and understand the English language with a degree of proficiency sufficient to fill out satisfactorily the juror qualification form"; (3) having the ability "to speak the English language"; (4) not possessing a "mental or physical infirmity" which would render one incapable of "satisfactory jury service"; and (5) not having a conviction or charge pending for a crime "punishable by imprisonment for more than one year" unless the person's civil rights have been restored. 28 U.S.C. $\$ 1865(\mathrm{~b})$.

31. 28 U.S.C. $\S 1863(\mathrm{~b})(6)$ lists persons who are exempt from jury service, including members of the military, firefighters, police officers, and public officials.

32. The court may excuse a potential juror on grounds of "undue hardship or extreme inconvenience." 28 U.S.C. $\$ 1863(b)(5)(A)$. 
jurors, or the "qualified jury wheel,"33 consists of those people who return questionnaires and meet the requirements for jury service.

Fifth, the court selects a list of prospective jurors to summon to the courthouse. This group is the "jury panel" or "venire." The JSSA provides that "the jury commission or the clerk shall publicly draw at random from the qualified jury wheel such number of names of persons as may be required for assignment to grand and petit jury panels." ${ }^{34}$ Thus, jury officials assign potential jurors to the venire by randomly selecting them from the list of qualified jurors.

Sixth, the court impanels the venire. Jury officials formally summon each member of the venire to court via registered, certified, or first-class mail, or via personal service. ${ }^{35}$ The court then eliminates potential jurors for reasons of excuse, exemption, or disqualification. Professors Fukurai, Butler, and Krooth have identified five factors that most significantly affect whether courts will excuse potential jurors from the verire: (1) economic hardship; (2) lack of child care; (3) age; (4) distance traveled and availability of transportation; and (5) illness. ${ }^{36}$

The seventh stage in the jury selection process is voir dire, the preliminary examination of potential jurors for competency and conflicts of interest. In federal court, the judge, the parties, or both conduct voir dire. ${ }^{37}$ In Duren v. Missouri, ${ }^{38}$ the Supreme Court held that the fair cross-section requirement applies to "jury wheels, pools of names, panels, or venires from which juries are drawn." ${ }^{39}$ Thus, the fair cross-section requirement applies up through the impanelment of the venire, but not to voir dire. ${ }^{40}$ The Federal Rules of Civil Procedure and the Fourteenth Amendment, not the Sixth Amendment, govern the removal of potential jurors for cause or by peremptory strikes. ${ }^{41}$

After voir dire, the jurors enter the jury box. There they complete the final stage in the jury selection process: election of a jury foreperson.

33. 28 U.S.C. $\S 1866(a)$.

34. Id.

35. 28 U.S.C. $\S 1866(b)$.

36. FuKURA, supra note 19 , at 64 .

37. See FED. R. Crv. P. 47(a) (providing that "[t] he court may permit the parties or their attomeys to conduct the examination of prospective jurors or may itself conduct the examination. In the latter event, the court shall permit the parties or their attomeys to supplement the examination by such further inquiry as it deems proper").

38. 439 U.S. 357 (1979).

39. Id. at 363-64 (quoting Taylor v. Louisiana, 419 U.S. 522,538 (1975)).

40. Brown, supra note 18 , at $445 \mathrm{n} .2$.

41. See FED. R. Civ. P. 47(c) (providing that "[t]he court may for good cause excuse a juror from service during trial or deliberation") (emphasis added); FED. R. CIv. P. 47(b) (authorizing peremptory challenges); Batson v. Kentucky, 476 U.S. 79, 89 (1986) (holding that the equal protection guarantce prohibits the racially motivated use of peremptory strikes). 
II

\section{The Fair Cross-Section Requirement}

\section{A. Doctrinal Origins}

Since the adoption of the Sixth Amendment in 1791, the notion of what constitutes an "impartial jury"42 has changed radically. Originally only property owners, a group composed exclusively of white inales, were eligible for jury service. ${ }^{43}$ In 1880 , the Supreme Court recognized the right of black inales to serve as jurors. ${ }^{44}$ Eventually the Supreme Court extended the same right to other "distinctive" or "cognizable" groups, including women and Mexican Americans. ${ }^{45}$

Until fairly recently, inost jury composition challenges focused on the equal protection rights of jurors. ${ }^{46}$ Beginning in 1940, with Smith $v$. Texas, ${ }^{47}$ the Supreme Court laid the framework for a new doctrinal approach. In Smith, the criminal defendant proved that jury officials in Harris County, Texas had intentionally and systematically excluded black citizens from grand jury service. ${ }^{48}$ The Court reversed Smith's conviction on the ground that enforcing an indictnent returned by sucli a jury violated the equal protection rights of the defendant. ${ }^{49}$ At that time, Texas used a "key-man" jury selection scheme, im which jury commissioners personally selected jurors froin the cominunity. ${ }^{50}$ The practical result of the key-man system, as applied in Texas, was the exclusion of black citizens from jury service. Although the Court upheld the key-man system, it stated for the first time that juries are "instruments of public justice" and therefore must

42. Recall that the Sixth Amendment guarantees trial by an "impartial jury," which the Supreme Court has held to mean a jury drawn "from a representative cross section of the community." See supra notes 1-2 and accompanying text.

43. Jon Van Dyke, Jury Selection Procedures 13-14 (1977).

44. Strauder v. West Virginia, 100 U.S. 303, 310 (1880) (holding that the exclusion of African American men from jury service on account of race violates the Equal Protection Clause of the Fourteenth Amendment); Virginia v. Rives, 100 U.S. 313, 321 (1880) (same). But see Thomas v. Texas, 212 U.S. 278, 282-83 (1909) (holding that exteusive underrepresentation of African Americans on grand and petit juries, absent proof of discriminatory intent on the part of jury commissioners, did not violate the Equal Protection Clause); Albert A. Alschuler \& Andrew G. Deiss, A Brief History of the Criminal Jury in the United States, 61 U. CH. L. Rev. 867, 894 (1994) (noting that for nearly a century courts did not enforce the right of Afriean Americans to serve on juries).

45. Taylor v. Louisiana, 419 U.S. 522, 538 (1975) (holding unconstitutional a Louisiana statute that required women to register for jury service but made men automatically eligible); Hernandez v. Texas, 347 U.S. 475, 482 (1954) (holding unconstitutional the exclusion of Mexican Americans from jury service).

46. See supra notes $44-45$.

47. 311 U.S. 128 (1940).

48. Id. at 129 .

49. Id. at 132 .

50. Id. at 131 n.5. The Court upheld Texas' jury selection process because it was capable "of being carried out with no racial discrimination whatsoever." Id. at 130-31. However, the majority warned that "[w] here jury commissioners limit those from whom grand juries are selected to their own personal acquaintance," unconstitutional "discrimination can arise from commissioners who know no negroes as well as from commissioners who know but eliminate them." Id. at 132 . 
be bodies "truly representative of the community." Th1 This assumption laid the foundation for the modern cross-section doctrine..$^{52}$

Two years later, in Glasser v. United States, ${ }^{53}$ the Supreme Court linked the notion of a representative jury to "basic concepts of a democratic society and a representative government" and to the Sixth Amendment rights of defendants. ${ }^{54}$ Glasser and two other defendants alleged that "they were denied an impartial trial" because the jury panel excluded "all women not members of the Illinois League of Woinen Voters." 55 The League had sponsored lectures by local prosecutors, ${ }^{56}$ and the Court found that the jury represented a special group with a "bias in favor of the prosecution." 57 The Court held that in order for the jury to be a "body truly representative of the community," it must reflect a "cross section of the community." 58 The Supreme Court further held that " $[t]$ he deliberate selection of jurors from the inembership of particular private organizations" violated the crosssection requireinent. . $^{59}$

Four years later, the Supreme Court employed the Glasser rationale to invalidate a federal jury-selection procedure that discriminated on the basis of economic class. In Thiel v. Southern Pacific Co., ${ }^{60}$ the Supreme Court held that jury officials could not intentionally exclude "daily wage earners" from federal jury service. ${ }^{61}$ The jury commissioner for the Northern District of Cahifornia stipulated that he "purposely excluded" all daily wage earners from the jury pool because judges historically tended to excuse such laborers from jury service on the basis of financial hardship. ${ }^{62}$ The Supreme Court held that the "wholesale exclusion of a large class of wage earners" as a matter of administrative convenience was impermissible. ${ }^{63}$ The Court announced that "those eligible for jury service are to be found in every stratum of society" and that "[j]ury competence is an individual rather than a group or class matter." ${ }^{\text {"64 }}$ Therefore, discrimmation against potential

51. Id. at 130 .

52. Under the fair cross-section doctrine, the right to have juries drawn from a representative jury pool is an inherent component of the Sixth Amendment's guarantee of an "impartial jury." The Court did not formally recognize this principle until Taylor v. Louisiana, 419 U.S. 522 (1975), which it decided thirty-five years after Smith.

53. 315 U.S. 60 (1942).

54. Id. at 85 .

55. Id. at 83 .

56. Id.

57. Id. at 86 .

58. Id.

59. Id.

60. 328 U.S. 217 (1946).

61. Id. at 224. The underlying dispute was a civil claim brought in federal court under diversity jurisdiction. Id. at 219.

62. Id. at 222.

63. Id. at 225 .

64. Id. at 220. The Court emphasized that the cross-section requirement "does not mean, of course, that every [grand or petit] jury must contain representatives of all the economic, social, religious, 
jurors on the basis of economic status was "abhorrent to the democratic ideals of trial by jury." ${ }^{\text {"65 }}$ The Court concluded that daily wage earners were a "substantial" group within the community ${ }^{66}$ and that jury officials could not exclude them from the federal jury-selection process altogether. Nonetheless, the Court noted that " $a$ federal judge would be justified in excusing a daily wage earner for whoin jury service would entail an undue financial hardship." 67

Although Thiel strongly suggested that a nonrepresentative jury panel could not produce an "impartial jury," the Supreme Court refused to follow the cross-section doctrine to its logical end. In subsequent cases, the Court interpreted the cross-section requirement as a mere prohibition against intentional discrimination by federal jury officials. ${ }^{68}$ The Court held that the underrepresentation of a distinct group, without evidence of discriminatory intent on the part of federal jury officials, did not violate the Sixth Amendment. In other words, the Supreme Court's cross-section methodology focused on discriminatory purpose, not on discriminatory effect.

As a result, the Supreme Court continued to uphold the constitutionality of key-man jury selection, absent evidence of intentional discrimination. ${ }^{69}$ Because this procedure relied on "key men in the community" to supply jury commissioners with a hist of potential jurors, it resulted in the substantial underrepresentation of racial and ethnic minorities and poor persons in federal jury pools. ${ }^{70}$ In 1966 , in Rabinowitz $v$. United States, ${ }^{71}$ the Fifth Circuit criticized key-man jury selection for causing this underrepresentation and questioned whether the key-man system violated the Supreme Court's cross-section requirement. ${ }^{72}$ Two years later, Congress responded to the Rabinowitz criticism with a sweeping reform of the federal jury system.

racial, political and geographical groups of the community; frequently such complete representation would be impossible." Id.

65. Id.

66. Id. at 223 (noting that "[w]age earners, including those who are paid by the day, constitute a very substantial portion of the community") (footnote omitted).

67. Id. at 224.

68. Until 1975 , the Supreme Court held that the cross-section doctrine "prohibited only systematic and intentional exclusions" from federal jury service. Handman, supra note 18, at 203 (citing Hamling v. United States, 418 U.S. 87, 137-38 (1974) (holding that the cross-section requirement prohibited only "purposeful discrimination" by jury officials)).

69. See Smith v. Texas, 311 U.S. 128 (1940) (rejecting a challenge to the key-man system); see also Handman, supra note 18, at 200 (stating that before the 1968 enactment of the JSSA, "Congress had not prescribed a uniform method for selection of federal grand or petit juries," but the most common federal selection procedure was the "key-man system").

70. Handman, supra note 18, at 200-01.

71. 366 F.2d 34 (5th Cir. 1966) (en banc).

72. Id. at 56-57; Handman, supra note 18, at 201. 


\section{B. The Jury Selection and Service Act}

In 1968 , Congress enacted the JSSA "to correct the racial and economic imbalances in federal jury composition and to establish uniform selection procedures." ${ }^{73}$ The JSSA provides that litigants in federal court entitled to jury trials have the right to grand and petit juries "selected at randoin froin a fair cross section of the community" in the district where the court convenes. ${ }^{74}$ It further provides that "[n]o citizen shall be excluded from [jury] service" in federal court "on account of race, color, religion, sex, national origin, or economic status." ${ }^{\prime 75}$ The JSSA requires each district court to adopt a written jury selection plan specifying "detailed procedures" that "ensure the random selection of a fair cross section of the persons residing im the community," ${ }^{\prime \prime 6}$ subject to review by a panel of federal judges. ${ }^{77}$ Each district court must prescribe sourccs for names of potential jurors and must ensure that these sources are sufficiently representative to "foster the policy and protect the rights" secured by the JSSA. ${ }^{78}$

In an outstanding student-written comment, Laura Handman argued that the legislative history of the JSSA suggests that Congress intendcd to make federal juries more representative, to eliminate the use of the key-man system im federal courts, and to provide uniform jury-selection standards for each district court. ${ }^{79}$ The House Committee Report on the JSSA stated that "as long as there are significant departures from the cross sectional goal, biased juries are the result-biased in the sense that they reflcct a slanted view of the community they are supposed to represent." ${ }^{\text {" }}$ (T) Senate Committee Report stated that "[a] jury chosen from a representative community sample is a fundamental of our system of justice." ${ }^{81}$ Debate on the House and Senate floors reflected the perception that the JSSA was consis-

73. Handman, supra note 18, at 201 (citing S. REP. No. 891, 90th Cong., 1st Sess. 10-11 (1967); H.R. REP. No. 1076, 90th Cong., 2d Sess. 4 (1968)).

74. 28 U.S.C. $\$ 1861$.

75. 28 U.S.C. $\$ 1862$.

76. 28 U.S.C. $\S 1863(b)(3)$.

77. 28 U.S.C. $\S 1863(\mathrm{c})$.

78. 28 U.S.C. $\S 1863(\mathrm{~b})(2)$. In addition, the JSSA establishes qualifications for federal jury service, $\S 1865$, sets out the process for selecting and summoning jury panels, § I866, describes the procedural requirements for challenging compliance with selection procedures, $\S 1867$, creates standards for the maintenance and inspection of jury records, $\S 1868$, and provides certain exemptions from federal jury service, $\S \S 1863(b)(5)$ and (6). For a brief overview of the jury selection process in federal courts, see supra Part I.

79. Handman, supra note 18 , at 201, 205-07; see also Taylor v. Louisiana, 419 U.S. $522,529 \mathrm{n} .8$ (1975) (stating that the "primary focus" of the JSSA was to eliminate "the "key man' system throughout the federal courts").

80. Taylor, 419 U.S. at 529 n.7 (citing H.R. REP. No. 1076, 90th Cong., 2d Sess. 8 (1968)).

81. Id. at 529 n.8 (citing S. REp. No. 891, 90th Cong., 1st Sess. 9 (1967)). 
tent with both the Sixth Amendment ${ }^{82}$ and the Supreme Court's fair crosssection doctrine. ${ }^{83}$

However, as Handman demonstrated, the JSSA does more than simply codify the Supreme Court's Sixth Amendment decisions. First, the Act expands the scope of the cross-section guarantee. While the Sixth Amendment applies only to criminal defendants, the ISSA applies to "all litigants in Federal courts entitled to trial by jury."84 Second, and more significantly, the JSSA requires the supplemental sources of potential jurors whenever "necessary to foster the policy and protect the rights secured by" the fair cross-section guarantee. ${ }^{85}$ The House and Senate Reports regarding the ISSA indicate that Congress intended the district courts to supplement their sources of potential jurors whenever any "substantial percentage deviation" exists between voting records and a fair cross section of the community ${ }^{86}$ In other words, Congress enacted the JSSA to "ensure crosssectional jury selection," rather than merely to prevent purposeful discrimination by jury officials. ${ }^{87}$ In fact, Congress expressly rejected a Justice Department proposal that would have mandated the supplementation of jury source lists only as a rcmedy for intentional discrimination in jury selection. ${ }^{88}$

According to Handman, Congress intended the ISSA to prohibit discriminatory effects, not merely discriminatory purpose. ${ }^{89}$ In other words, the JSSA does more than prohibit mvidious discrimination by federal officials who administer the jury system (discriminatory purpose). The statute also protects against the selection of jury venires from a pool that results in consistent underrepresentation of certain groups (discriminatory effect). According to this view, the ISSA forbids jury selection procedures that, althougl facially neutral, result in the underrepresentation of distinctive cominunity groups on jury venires.

\section{Developments in the Fair Cross-Section Doctrine Since the Enactment of the JSSA}

Since the enactinent of the JSSA, the Supreme Court has modified the cross-section doctrine in two significant ways. First, the Court has formally stated that a grand or petit jury must be drawn from "a representative cross

82. Id. at 530 (citing 114 CoNg. Rec. 3992 (1968) (remarks of Mr. Rogers); 118 Cong. Rec. 6939 (1972) (remarks of Mr. Poff)).

83. Id. (citing 114 CoNG. Rec. 6609 (1968) (remarks of Sen. Tydings)).

84. 28 .U.S.C. $\$ 1861$. This includes civil litigants entitled to a jury trial. See supra note 7 and accompanying text.

85. 28 U.S.C. $\S 1863(b)(2)$.

86. Handman, supra note 18, at 205 (citing S. REP. No. 891, 90th Cong., 1st Sess. 17 (1967); H.R. Rep. No. 1076, 90th Cong., 2d Sess. 5 (1968)).

87. Id.

88. Id.

89. Id. at 205-06. 
section of the community" in order to satisfy the Sixth Amendment's guarantee of trial by an impartial jury. ${ }^{90}$ Second, the Court seemingly has abandoned its focus on discriminatory purpose and changed the requirements for a "prima facie violation of the fair-cross-section requirement." 1

The most significant fair cross-section case since the enactment of the JSSA is Taylor v. Louisiana. ${ }^{92}$ Taylor argued that Louisiana's "opt-in" jury selection process, which automatically included inen on the master jury list, but only included women if they registered with local jury officials, violated his Sixth Amendment right to a trial by an impartial jury. Women comprised fifty-three percent of the persons eligible for jury service in the district, but only ten percent of the jury wheel. ${ }^{93}$ Before considering the merits of Taylor's claim, the Court established that a defendant need not be a member of the allegedly underrepresented group in order to challenge the composition of the jury wheel. ${ }^{94}$ Next, the Court noted that, although Louisiana did not disqualify women froin jury service, the systematic inpact of Louisiana's "opt-in" procedure was "that only a very few women ... [were] called for jury service." 95 Although no prior Supreme Court opinion had squarely held that the exclusion of women from jury venires deprives a criminal defendant of her Sixth Amendment right to trial by an impartial jury, the Taylor Court announced that the "unmistakable import of this Court's opinions, at least since $1940 \ldots$ is that the selection of a petit jury from a representative cross section of the community is an essential coinponent of the Sixth Amendment right to a jury trial."196 Therefore, the Court found that Taylor made a prima facie showing that Louisiana's jury selection process violated the Sixth Amendment.

The primary significance of the Taylor decision was the Supreme Court's forinal recognition that in order to satisfy the impartial-jury requirement, "petit juries must be drawn from a source fairly representative of the community."97 However, the opinion left at least two major issues unresolved. First, what did the Court mean when it held that "jury wheels, pools of names, panels or venires" must not "systematically exclude" dis-

90. Taylor v. Louisiana, 419 U.S 522, 528 (1975).

91. Duren v. Missouri, 439 U.S. 357, 364 (1979). See infra text accompanying note 102.

92. 419 U.S. 522 (1975).

93. Id. at 524 .

94. Id. at 526 (citing Peters v. Kiff, 407 U.S. 493 (1972)).

95. Id. at 525.

96. Id. at 528.

97. Id. at 538. The Court qualified the scope of its decision by stating, "in holding that petit juries must be drawn from a source fairly representative of the community we impose no requirement that petit juries actually chosen must mirror the community and reflect the various distinctive groups in the population. Defendants are not entitled to a jury of any particular composition." Id. (citing Fay v. New York, 332 U.S. 261, 284 (1947); Apodaca v. Oregon, 406 U.S. 404, 413 (1972) (plurality opinion)). 
tinctive groups in the community? Second, what is a "distinctive group" for Sixth Amendment purposes? ${ }^{98}$

Four years later, in Duren v. Missouri, ${ }^{99}$ the Supreme Court resolved the first of these questions, defining what it meant to "systematically exclude" a group from the jury selection process. Duren alleged that Missouri's jury-selection procedure, which granted women an automatic exemption from jury service if they so requested, violated the fair crosssection requirement. ${ }^{100} \mathrm{He}$ presented evidence that women comprised fiftyfour percent of the adult population of Jackson County, Missouri, but less than twenty-seven percent of those summoned for jury service and approximately fifteen percent of those present on venires. ${ }^{101}$ In response, the Court announced a three-prong test for determining whether a jury pool represents a fair cross section of the community. To make a prima facie showing that the composition of the jury wheel does not represent a fair cross section, a petitioner inust demonstrate the following: "(1) that the group alleged to be excluded is a 'distinctive' group in the community; (2) that the representation of this group in venires from which juries are selected is not fair and reasonable in relation to the number of such persons in the community; and (3) that this underrepresentation is due to systematic exclusion of the group in the jury-selection process." 102

In Duren, the petitioner readily met the first two prongs of the Court's test. ${ }^{103}$ Therefore, the critical issue was whether the petitioner had shown "that the underrepresentation of women, generally and on his venire, was

98. Another issue that Taylor left unresolved was which component of the Sixth Amendment's guarantee of an "impartial jury" necessitates cross-sectional representation. In Holland v. 1llinois, 493 U.S. 474, 480 (1990), the Court stated that "[t]he Sixth Amendment requirement of a fair cross section on the venire is a means of assuring, not a representative jury (which the Constitution does not demand), but an impartial one (which it does)." Three Justices disagreed, arguing that "the fair-cross-section requirement is not based on the constitutional demand for impartiality; it is founded on the notion that wbat is denominated a 'jury' is not a 'jury' in the eyes of the Constitution unless it is drawn from a fair cross section of the community." Id. at 494 (Marshall, J., joined by Brennan and Blackmun, JJ., dissenting). See also Darryl K. Brown, The Role of Race in Jury Impartiality and Venue Transfers, 53 MD. L. REv. 107, 113 n.29 (1994) (noting that there are differing interpretations of the constitutional basis for the fair cross-section requirement).

99. 439 U.S. 357 (1979).

100. Id. at 360 .

101. Id. at 362 .

102. Id. at 364. Similarly, courts have construed the JSSA's fair cross-section requirement as focusing on the inclusion of all "cognizable classes." See Handman, supra note 18, at 208 (citing United States v. Diggs, 522 F.2d 1310, 1316 (D.C. Cir 1975); United States v. Ross, 468 F.2d 1213, 1217 (9th Cir. 1972)); see also United States v. Hafen, 726 F.2d 21, $22 \mathrm{n.1}$ (1st Cir.) (1989) (stating that courts have construed the Sixth Amendment and the JSSA as functional equivalents), cert. denied, 466 U.S. 962 (1984).

In addition to the Sixth Amendment and the JSSA, a petitioner may base a challenge to the composition of the jury wheel on the Equal Protection Clause or on the Due Process Clauses of the Fifth and Fourtcenth Amendments. See Peter A. Detre, A Proposal for Measuring Underrepresentation in the Composition of the Jury Wheel, 103 Y ALE L.J. 1913, 1914 (1994).

103. Duren, 439 U.S. at 364-66. 
due to their systematic exclusion in the jury-selection process."104 The Court stated that underrepresentation is "systematic" if it is "inherent in the particular jury-selection process utilized." 105 Because "a large discrepancy" between the number of women eligible for jury service and the number of women impaneled on the venire "occurred not just occasionally, but in every weekly vemire for a period of nearly a year," the Court held that there was systematic underrepresentation. ${ }^{106}$ Thus, the systematic exclusion component of the Duren test abandoned the Court's earlier requirement of discriminatory purpose in favor of an emphasis on discriminatory effects. ${ }^{107}$

\section{The Meaning of "Distinctive" Groups}

Taylor and Duren established that the fair cross-section doctrine requires the inclusion of "distinctive" groups. ${ }^{108}$ The Supreme Court has not clearly defined what makes a particular group distinctive for purposes of the Sixth Amendment. ${ }^{109}$ However, in Lockhart v. McCree, ${ }^{110}$ the Court stated that "we think it obvious that the concept of 'distinctiveness' inust be hinked to the purposes of the fair-cross-section requirement."111 Citing Taylor, the Court identified three such doctrinal objectives: (a) to guard against the arbitrary exercise of prosecutorial authority; (b) to preserve "public confidence in the fairness of the criminal justice system"; and (c) to

104. Id. at 366 (emphasis added).

105. Id.

106. Id. Of course, this finding raises the question of how much underrepresentation is necessary to show "a large discrepancy." As noted, the second prong of the Duren test requires a petitioner to prove that the representation of a group "is not fair and reasonable in relation to the number of such persons in the community." Id. at 364. However, this test provides no standards for defining what "fair and reasonable" means. See Detre, supra note 102, at 1927-30 (discussing the competing methodologies for measuring underrepresentation).

107. Brown, supra note 18 , at 465 (stating that the Duren test "connotcs consistcncy rather than intention, the clear pattern resulting from a policy choice rather than a discriminatory purpose"); see also Laurie Magid, Challenges to Jury Composition: Purging the Sixth Amendment Analysis of Equal Protection Concepts, 24 SAN Drego L. REv. 1081, 1090-91 (1987) (stating that it is easier to show a prima facie violation under Sixth Amendment fair cross-section analysis than under Fourteenth Amendment equal protection analysis, because it is not necessary to show discriminatory intent).

108. See supra text accompanying notes 98,102 . As noted in the previous Section, a prima facic violation of the fair cross-scction requirement includes three elements: 1) a distinctive group allcges underrepresentation; 2) representation of that group on jury venires is not fair and reasonable; and 3) this underrepresentation is due to systematic exclusion. See supra text accompanying note 102. The remainder of this Comment will focus on the doctrine surrounding the first of these elcments: the distinctiveness of particular social groups.

109. See Lockhart v. McCree, 476 U.S. 162, 174 (1986) (stating that the Court has "nevcr attempted to precisely define the term 'distinctive group,' and we do not undertake to do so today"). Of course, even before formulating the Duren test, the Supreme Court prohibited the systematic exclusion of women, blacks, Mexican Americans and "daily wage earners" from jury pools. See supra notcs 44$45,60-67$ and aecompanying text.

110. 476 U.S. 162 (1986).

111. Id. at 174 . 
promote shared responsibility for the administration of justice as a "phase of civic responsibility." 112

The Lockhart Court also discussed groups that it did not define as distinct for fair cross-section purposes. The Court held that "Witherspoonexcludables," prospective jurors who refuse to impose the deatl penalty, were not a distinctive group for fair cross-section purposes. ${ }^{113}$ The Court stated that the exclusion from jury service of a group "defined solely in terms of shared attitudes" does not "contraven[e] any of the basic objectives of the fair-cross-section requirement." 114 The Court furtlier suggested that an attribute that is "within the individual's control" cannot define a distinctive group for jury-selection purposes. ${ }^{15}$ The Court emphasized that "Witherspoon-excludables" were unlike the groups it had previously recognized as distinctive: African Americans, Mexican Americans, and women. ${ }^{116}$ Jury officials had excluded each of these distinctive groups "on the basis of some immutable characteristic sucl as race, gender, or ethnic background."117 The exclusion of these groups from jury service, the Court argued, denies criminal defendants the "benefit of the common-sense judgment of the community" as a protection against arbitrary governmental power. ${ }^{118}$ In addition, the Court stated that excluding such groups creates an "appearance of unfairness," whicli undermines public confidence in the criminal justice system. ${ }^{119}$ Finally, the wholesale exclusion of potential jurors based on race, gender, or ethnic background deprives members of historically disadvantaged groups of their rights as citizens to participate in the administration of justice. ${ }^{120}$

For purposes of this Comment, the most significant aspect of the Lockhart opinion was the Supreme Court's omission of "daily wage earners" from its list of distinctive groups. Although attempting to interpret the Supreme Court's silence is conjectural, this significant omission suggests that the majority intended to distinguish Thiel from the Court's more recent Sixth Amendment opinions. Althougli the Supreme Court did not provide any additional guidance, the First Circuit subsequently stated in Anaya $v$. Hansen "121 that Thiel "cannot be read as mandating that blue collar workers are a 'cognizable group' as that term was used in Duren."122 The Anaya court held that "blue collar workers" are not a "distinctive group" for whom

112. Id. at 174-75.

113. Id. at 174 .

114. Id. at $176-77$.

115. Id. at 176.

116. Id. at 175. Note that the Court did not list "daily wage earners" as an example of a distinctive group, despite its prior holding in Thiel.

117. Id.

118. Id.

119. Id.

120. Id.

121. 781 F.2d 1 (1st Cir. 1986).

122. Id. at 4 . 
"a mere showing of statistical underrepresentation, with little more, indicates a prima facie violation of the Sixth Amendment."123 The First Circuit stated that the result in Thiel stemmed from the fact that jury officials there "created [their] own group" by intentionally excluding all daily wage earners. ${ }^{124}$ The court concluded that Thiel applied only in the context of deliberate discrimination by jury officials and thus did not provide guidance for the question of whether "blue collar workers" constitute a distinctive group for purposes of a Duren analysis. ${ }^{125}$ As the next Section demonstrates, several other courts have followed the Anaya court's rationale and have refused to recognize groups defined by economic status as distinctive.

\section{E. The Rejection of the Poor as a Distinctive Group}

The meaning of a distinctive group is fairly well-developed in the context of the JSSA. Federal courts in every district perform the same basic inquiry. Absent proof of intentional discrimination, a JSSA claimant must demonstrate that members of the alleged group share: (a) some attribute that defines and limits the group; (b) a common attitude, idea, or experience that distinguishes the group from other segments of society; and (c) a "community of interest" that the jury pool would not adequately reflect if it excluded members of the group. ${ }^{126}$ In cases where claimants did not prove purposeful discrimination, courts have rejected fair cross-section claims alleging the distinctiveness of the following groups: "poor people,"127 the "lower socioeconomic class,"128 "persons with low mcomes,"129 a "lower economic group,"130 "food stamp recipients,"131 "non-working people,"132

123. Id.

124. Id.

125. Id. at 4-5. See also Barber v. Ponte, 772 F.2d 982, 985 (1st Cir. 1985) (stating that Thiel did not hold "that daily wage eamers had a particular community of interest or values distinct from the rest of the population," but merely prohibited jury officials from discriminating against persons of "low economic and social status'), cert. denied, 475 U.S. 1050 (1986).

126. See, e.g., United States v. Guzman, 337 F. Supp. 140, 143-44 (S.D.N.Y.), aff'd, 468 F.2d 1245 (2d Cir. 1972), cert. denied, 410 U.S. 937 (1973). For an alternate annunciation of the same basic test, see, e.g., United States v. Test, 550 F.2d 577, 591 (10th Cir. 1976) (holding that to establish the distinctiveness of a group, a claimant must prove some quality or attribute defining and limiting the group; a cohesiveness of attitutes or ideas or an experience that distinguishes the group from the general social milieu; and a community of interest that other segments of society may not adequately represent; or, the claimant must present evidence other than such factors from which the court may presune or infer the cognizability of the group).

The second and third of these clements do not appear to constitutc separate requirements; courts tend to define a community of interest as a similarity of attitudes, ideas, or outlook. See infra Part III.C.

127. See, e.g., United States v. James, 453 F.2d 27, 29 (9th Cir. 1971); Commonwcalth v. Rosado, 26 Phila. 22, 1993 Phila. Cty. Rptr. LEXIS 21, *16-*18 (Phila. County 1993).

128. See United States v. Abell, 552 F. Supp 316, 322 (D. Me. 1982).

129. See Quadra v. Superior Court, 378 F. Supp. 605, 621 (N.D. Cal. 1974).

130. See United States v. Greene, 489 F.2d 1145, 1150 (D.C. Cir. 1973), cert. denied, 419 U.S. 977 (1974).

131. See United States v. MeDaniels, 370 F. Supp. 298, 312 (E.D. La. 1973), aff'd sub nom. United States v. Goff, 509 F.2d 825 (5th Cir.), cert. denied, 423 U.S. 857 (1975).

132. See United States v. Kleifgen, 557 F.2d 1293, 1296 (9th Cir. 1977). 
and "paupers."133 Courts also have rejected the notion that "blue collar workers," 134 the "working class,"135 and the "urban working class"136 are distinctive.

Attempts to define distinctive groups in terms of occupation, income, or wealth have failed at a variety of levels. Some challengers have failed to delineate with adequate precision the allegedly underrepresented group. For example, in Anaya v. Hansen, the First Circuit held that the term "blue collar workers" is too imprecise to clearly define a judicially cognizable group. ${ }^{137}$

Other courts have rejected the notion that persons in similar economic circumstances share a common experience or a basic similarity in outlook. For example, in United States v. McDaniels, ${ }^{138}$ the United States District Court for the Eastern District of Louisiana held that "food stamp recipients" and "the poor" were not cognizable groups. ${ }^{139}$ Although these groups were clearly definable, the court rejected the claim that members shared common qualities or outlooks. ${ }^{140}$ The court held that our nation "has an almost infinite number of gradations in income and net worth,"141 such that there is no clear "standard of who is poor and who is not poor." "There can be little doubt," the court argued, that a married couple that nearly qualified for food stamps, but had an annual income just barely too high, "would consider themselves 'poor." "143 Therefore, while "[t] $]$ he classification of persons by a specific dollar income ... serves a useful function to determine who may be eligible for a public benefit, ... it is entirely arbitrary if used as the sole

133. See United States v. Amett, 342 F. Supp. 1255, 1261 (D. Mass. 1970).

134. See Anaya v. Hansen, 781 F.2d 1, 8 (1st Cir. 1986); United States v. Cabrera-Sarmiento, 533 F. Supp. 799, 804, 807 (S.D. Fla. 1982); Quadra, 378 F. Supp. at $621-22$ (holding that the category of blue collar workers was "too imprecise and undoubtedly over-inclusive" given the high wages paid to many craftspeople).

135. See United States v. Marcano, 508 F. Supp. 462,469 (D.P.R. 1980); Figueroa v. Puerto Rico, 463 F. Supp. 1212, 1214 (D.P.R. 1979).

136. See United States v. Valentine, 288 F. Supp. 957, 974 (D.P.R. 1968). For purposes of simplicity, this Comment will refer to all of the aforementioned groups, supra notes 127-136, collectively as "the poor."

137. Anaya v. Hansen, 781 F.2d 1, 5 (1st Cir. 1986) (holding that, although "there are some workers who can be clearly identified as 'blue collar, . . . at a certain point the term fades into ambiguity"). The court further stated that even if the term somehow did describe a sufficiently welldefined group, "findings of cognizability have been limited to special groups, like women and blacks, that have been subjected to discrimination and prejudice within the community." Id. at 6 . See also United States v. Marcano, 508 F. Supp. 462,469 (D.P.R. 1980) (holding that "persons of the working class or of lower socioeconomic status" are classifications "too ambiguous and loose to support any finding of a distinct, identifiable class").

138. United States v. McDaniels, 370 F. Supp. 298 (E.D. La. 1973), aff'd sub nom. United States v. Goff, 509 F.2d 825 (5th. Cir.), cert. denied, 423 U.S. 857 (1975).

139. Id. at 312 .

140. Id. at 308 .

141. Id.

142. Id. at 307.

143. Id. 
criterion of economic status or of poverty, for jury purposes."144 The court also stated that "[u]nlike race, religion, sex or national origin, which are determinable bimarially," 145 a person's economic status "might well change from one year to the next." 146 The court thus concluded that any attempt to define a group "with respect to its presumed qualities or outlook" stemming from income or economic status "would be entirely artificial."147 Similarly, courts have rejected the notion that persons of low econoinic status share a "commumity of imterest" that other segments of society cannot adequately represent. ${ }^{148}$

Finally, some courts have refused to recogmize the poor as a distinctive group on the ground that such recognition should apply only to groups that "have been subjected to discrimination and prejudice within the community." ${ }^{149}$ In Anaya v. Hansen, ${ }^{150}$ the First Circuit argued that this requirement was necessary to distinguish the distinctive groups that inatter for jury selection purposes from the "literally thousands of "cognizable groups" present in society, including "barbers, overweight persons, Red Sox fans, scoutnasters, Marine veterans, radio amateurs, and so on, ad infinitum."151

\section{III}

\section{The Failure of the Current Distinctiveness Doctrine}

Part II demonstrated that federal courts have not recognized the poorwhether defined in terms of annual income, occupation, food stamp eligibility, socioeconomic status, or other criteria-as a distinctive group for jury selection purposes. The courts have offered three major explanations for this result. First, economic status is too complicated a concept to be defined meaningfully in terms of a single factor, such as incoine or occupation. Second, one's economic status is subject to constant change and is therefore incapable of ineamingful differentiation over time. Third, the poor do not share a community of interest; alternately stated, persons who share similar economic circumstances do not share common, distinctive attitudes. ${ }^{152}$

This Part challenges the validity of these assumptions. It argues that courts have overstated the difficulty of defining a distinctive group based on

144. Id.

145. Id.

146. Id. at 308 .

147. Id. at 307-08.

148. See, e.g., Anaya v. Hansen, 781 F.2d 1, 6 (1st Cir. 1986) (arguing that the diversity and varying compensation levels of blue collar jobs prevents the development of a community of interest based on economic status).

149. Id.

150. 781 F.2d 1 (1st Cir. 1986).

151. Id. at 6 .

152. The first and second of these rationales bear on the first element of the doctrinal test for distinctiveness-the definability of the group. The community of interest explanation encompasses the second and third elements of the test-labelled separately as the "shared attitudes" element and the "community of interest" element. See supra Part II.E. 
economic status and understated the difficulty of defining other cognizable groups. As a result, the current doctrinal test is unpersuasive. Careful review demonstrates that the doctrine is poorly reasoned and does not appropriately take into account the particular requirements imposed by the jury context. Lacking a principled basis for determining whether a given group is distinctive, courts have improvised. This improvisation has led to the collapse of the test for distinctiveness into a single inquiry: have meinbers of the underrepresented group "been subjected to discrimination and prejudice within the community" ${ }^{153}$ Unfortunately, this methodology is also flawed. It fails to provide a reasoned distinction between groups recognized as distinctive and other groups im society, and it conflates distinct Sixth Amendment and Fourteenth Amendment imquiries.

\section{A. Determinability}

Many courts have justified their refusal to consider the poor to be a distinctive group on grounds of determinability. In essence, these courts contend that it is too difficult to determine who is poor at any one time. For example, in United States $v$. McDaniels ${ }^{154}$ the court lield that the poor are not a distinctive group for jury selection purposes because the quality that defines the group economic status-"has an almost infinite number of gradations." 155 The court contrasted "race, religion, sex or national origin, whicl are determinable binarially," to economic status, which "is entirely a matter of degree."156 Since economic status is not a bimary characteristic, the court dismissed any distinction between the poor and the nonpoor as "an illusion."157 The court concluded that any group defined by annual income or food stamp eligibility was "arbitrary," and therefore not judicially cognizable. ${ }^{158}$ Other courts lave applied similar reasoming. ${ }^{159}$

Admittedly, there is no clear dividing lime between who is poor and who is not. Any attempt to construct such a boundary is subjective and imprecise. But meaningful differentiation on the basis of economic status is neither inpossible nor undesirable. Since the 1960s, the federal governinent has distinguished between the poor and the nonpoor by using the poverty line. The poverty line consists of a set of income cutoffs adjusted for lousehold size, number of dependent children, and the age of the household

153. Anaya, 781 F.2d at 6 .

154. 370 F. Supp. 298 (E.D. La. 1973), aff'd sub nom. United States v. Goff, 509 F.2d 825 (5th Cir.), cert. denied, 423 U.S. 857 (1975).

155. Id. at 308.

156. Id. at 307.

157. Id.

158. Id. at 307-08.

159. See, e.g., Anaya v. Hansen, 781 F.2d 1, 5 (1st Cir. 1986) (holding that blue collar workers are not a cognizable group, in part because they are not "defined and limited by some clearly identifiable factor" such as "sex or race") (citing Barber v. Ponte, 772 F.2d 982, 997 (1st. Cir. 1985), cert. denied, 475 U.S. 1050 (1986)). 
head. ${ }^{160}$ Individuals and households whose pretax cash income fall below the poverty lime are poor; those with incomes above the line are not. ${ }^{161}$ Based on 1992 data, the poverty line ranged from $\$ 6729$ for a single person aged sixty-five or older to $\$ 21,594$ for a household of seven or more. ${ }^{162}$ The figure for a fainily of four was $\$ 14,335 .{ }^{163}$ While critics question the precision of this inethodology, ${ }^{164}$ it is conceptually clear and administratively manageable.

Imprecision is not a problein unique to measuring income. Laws frequently require public officials to identify and differentiate between groups of citizens. Some categories are relatively easy to differentiate and administer, such as gender, ${ }^{165}$ age, and marital status. Other differentiating principles are less objective and thus more difficult to admimister. Consider the categories of "race" and "ethnicity." The McDaniels court stated that race is a "binary" classification which-unlike econoinic status-is not merely a matter of degree. ${ }^{166}$ Contrary to the court's assertion, however, race is an extremely complicated issue, not a monochromatic distinction between white and non-white, or people of color and others. ${ }^{167}$

Scientists and scholars generally agree that the concept of race lacks biological significance. ${ }^{168}$ Many commentators suggest that "[a] person's

160. Originally, the government set these cutoffs at three times the minimum amount of money necessary to purchase a "nutritionally adequate" diet as determined by the Department of Agriculturc; since then, it has calculated poverty thresholds by multiplying the previous year's cutoffs by the Consumer Price Index. House Comm. on Ways and Means, 103d Cong., 2d Sess., Overview of EntTtLement Programs 1152 (Comm. Print 1994) [hereinafter Green Book].

161. Id. at 1552. The government does not consider noncash benefits (sucb as Food Stamps, subsidized housing, school lunch, and the fungible value of Medicaid) for purposes of detcrmining whether one's income falls below the offieial poverty line. Id. at 1163.

162. Id. at 1155 (citing 1992 Bureau of Census data). In general, the most recent data contained in the GREEN BooK is for the year 1992.

163. Id.

164. Some crities argue that the poverty line is unrealistically low because the average family spends five times its food budget for housing, clothing, child care, and other necessities. Others argue that the poverty line overestimates the extent of poverty because it does not count nonmonctary bencfits, such as Food Stamps, subsidized housing, or Mcdicaid, as annual income. For a summary of criticisms of the federal methodology for measuring poverty, see Jason DeParle, In Rising Debate on Poverty, The Question: Who is Poor?, N.Y. Times, Sept. 3, 1990, at Al, Alo.

165. See Christopher A. Ford, Administering Identity: The Determination of "Race" in RaceConscious Law, 82 CALIF. L. REv. 1231, 1237 (1994) (stating that "human beings come only in two biological fiavors, each fairly easily distinguishcd by a characteristic chromosomal pattern of $\mathrm{XX}$ (female) or XY (male)"); cf. Francisco Valdes, Queers, Sissies, Dykes and Tomboys: Deconstructing the Confation of "Sex," "Gender," and "Sexual Orientation" in Euro-American Law and Society, 83 CAurF. L. REv. 1 (1995) (exploring the conflation of sex, gender, and sexual orientation).

166. United States v. McDaniels, 370 F. Supp. 298, 307 (E.D. La. 1973), aff'd sub nom. United States v. Goff, 509 F.2d 825 (5th Cir.), cert. denied, 423 U.S. 857 (1975).

167. See, e.g. Tom Morganthau, What Color Is Black?, Newsweek, Feb. 13, 1995, at 63 (discussing controversies surrounding the Census Bureau's racial classification system).

168. See generally Ian F. Haney López, The Social Construction of Race: Some Observations on Illusion, Frabrication, and Choice, 29 HARv. C.R.-C.L. L. REv. I (I994); Sharon Begley, Three Is Not Enough: Surprising New Lessons From the Controversial Science of Race, NewsweEK, Feb. 13, 1995 at 67 (stating that approximately $70 \%$ of cultural anthropologists reject race as a biological category); 
racial identity is largely a social phenomenon, rather than a biological one."169 Census data reveal the crudeness of current methods of "administering race" and the complexity of racial identity. The 1990 U.S. Census asked respondents to identify themselves as members of one of six racial groups: White, Black, Asian or Pacific Islander, American Indian, Eskimo or Aleut, or "Other." In response, Americans claimed membership in approximately 300 different racial groups, 600 Native American tribes, and 75 combinations of multiracial ancestry. ${ }^{170}$ This response demonstrates an overwhelming rejection of a "binary" notion of racial identity.

Ethnicity is an even more problematic concept. As Christopher Ford queries, "what are we to make of 'ethnic' identity, in which a host of indefinable cultural, educational, and environmental factors complicate these already-muddy waters?"171 For example, there is no uniform definition of who is "Hispamic." Commentators suggest that Latimos and Latinas share a cultural identity rather than an ethnic one. ${ }^{172}$ Indeed, members of many racial and ethnic groups identify themselves as Hispamic. In the 1990 Census, for example, members of seventy different ethnic groups reported they were of "Hispanic origin." 173

Furtherinore, different government agencies have adopted different definitions of who is Hispanic. For example, Department of Labor rules provide that in the context of the Equal Employment Opportunity (EEO) progran1, a person of "Hispanic origin" cannot be "Black."174 In contrast,

Charles Petit, Scientists Call Race Insignificant: They Say Differences Are Mostly Superficial, S.F. ChroN., Feb. 20, 1995, at Al, Al3 (reporting that a panel of evolutionary biologists, anthropologists, and geneticists from the American Association for the Advancement of Science believes that race lacks biological significance). But see Richard J. Herrnstem \& Charles Murray, The Bell Curve (1994) (arguing that race has biological significance).

169. See Ford, supra note 165, at 1239 (citing Kingsiey R. Browne, Biology, Equality, and the Law: The Legal Significance of Biological Sex Differences, 38 Sw. L.J. 617, 666-67 (1984)); see also Angela P. Harris, Foreword: The Jurisprudence of Reconstruction, 82 CaLIF. L. Rev. 741, 771-72 (1994) (stating that race is "nowadays widely seen as having little or no objective existence") (citations omitted).

170. Morganthau, supra note 167 , at 65 .

171. Ford, supra note 165 , at 1239.

172. E.g., Morganthau, supra note 167, at 64 (stating that "Latinos are neitber a 'race' nor an 'ethnic group.' They are a disparate collection of nationalities variously descended from Europeans, African slaves and American Indians.").

173. Id. at 65 . In the 1990 Census, the Census Bureau's long form posed four separate questions regarding race, ethnicity, and national origin. First, it asked each respondent to indicate which race she considered herself to be. Second, the form inquired whether the respondent was of "Spanish/Hispanic origin." Third, the form asked cach person to report her ancestry or ethnic origin. Finally, it requested each respondent to indieate the U.S. state or foreigu country of her birth. Ford, supra note 165, at 1242 \& n.55. Therefore, a respondent could indieate both Hispanic origin and a separate ethnic identity. For example, one could "enter a procedurally valid self-reported response of Eskimo (race), Argentinian (Hispanic origin), Nigerian (ancestry/ethnicity), and Ukrainian (national origin)." Id. at 1242 n.55.

174. Ford, supra note 165 , at 1246 n.71 (citing 41 C.F.R. $\$ 60-4.3$ (a)(1)(d) (1993)). Despite this provision, the regulations state that Hispanics are defined "regardless of race." Id. (citing 41 C.F.R. $\S 60-4.3$ (a)(1)(d) (1993)). Oddly, many EEO regulations refer not to "Hispanics" but to "Spanishsurnamed Americans." Id. (citing 41 C.F.R. $\$ 60-2.11$ (a) (1993)). 
under the Federal Bureau of Investigation's "Uniform Crime Reporting" criteria, "Hispanic" persons are those of any "Spanish culture or origin, regardless of race."175 The Census Bureau places no racial restrictions on which groups it will classify as Hispanic. ${ }^{176}$ However, it does restrict the number of ethnic groups that can clain Hispanic origins. ${ }^{177}$ In sun1, there is no consistent approach to defining this group. ${ }^{178}$

I am not suggesting that attempts to "administer race" are hopelessly arbitrary, or that race and ethnicity do not nuatter. My point is that racial and ethnic identity-like economic status-are socially constructed categories that lack precise boundaries. Put siniply, these categories are not "binary." The demarcation line between the poor and the nonpoor is no more illusory than the factors used to differentiate between members of different races and ethnicities. In fact, as Christopher Ford suggests, "categories of race and ethnicity are analytically 'slippery' in a way that indicia of income . . . [are] not."179 Nonetheless, the Supreme Court has held that some racial and ethnic groups, such as African Americans and Mexican Americans, are distinctive for jury selection purposes. Therefore, the claim that it is impossible to define and linit the poor using a clearly identifiable factor, such as annual incone, is unpersuasive. This prong of the current distinctiveness test cannot distinguish the poor from other groups already recognized as distinctive.

\section{B. Immutability}

Some courts have held that the poor are not a distinctive group because economic status is not an immutable characteristic, but one that "might well change from one year to the next."180 The McDaniels court applied this rationale to reject economic status as a basis for defining a distinctive group. ${ }^{181}$ Although it is true that poverty is not always a permanent characteristic, the poor are not as fluid a group as courts imply. While the available empirical evidence admittedly is not conclusive, ${ }^{182}$ it indicates that

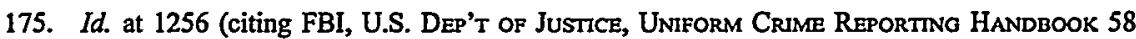
(1984)).

176. Id.

177. See id. at 1242 (stating that the Census form's question regarding Hispanic origins specifies a "handful of permissible responses").

178. Approximately $95 \%$ of the respondents to the 1990 Census who identified their race as "Other" wrote in the names of Hispamic subgroups as their racial identities. Id. at 1243. Because the Census Bureau does not consider Hispanic groups to be races, it adopted a "Race Assignment Rule" that classified each of these respondents "as being of the same race as [that specified by] their nearest family member, housing-bloc co-resident, and so forth." Id.

179. Id. at 1242 (emphasis added).

180. See, e.g., United States v. McDaniels, 370 F. Supp. 298, 308 (E.D. La. 1973), aff'd sub nom. United States v. Goff, 509 F.2d 825 (5th Cir.), cert. denied, 423 U.S. 857 (1975).

181. Id. at 309 .

182. As mentioned above, the official measure of poverty in the United States is the Census Bureau's poverty line. See supra notes 161-164 and accompanying text. Unfortunately, the Census Bureau data tables provide only a "snapshot" of the total number of poor persons in any given year. 
poverty is frequently not a transitory condition. ${ }^{183}$ Those who grow up in poverty tend to stay poor. ${ }^{184}$ Moreover, during the past four decades, there has been relative stability in the economic position of the lowest quintile of households. ${ }^{185}$ A recent study revealed that thirty-five percent of urban residents who were poor in 1979 also fell below the poverty line during at least eight of the ten years from 1974 to $1983 .{ }^{186}$ Extrapolating from this data, one researcher has concluded that between $4.9 \%$ and $8.8 \%$ of the American population lives in persistent poverty. ${ }^{187}$ Thus, as Laura Handman reminds us, the poor are not a group "whose characteristics are so difficult to establish with certainty and change so frequently that ineaningful identification of the group is rendered inpossible." 188

Moreover, while the coinposition of the poor nay be soinewhat fluid, the social problein of poverty appears to be anything but temporary. Commentators from across the political spectrum express frustration at the

Sheldon Danziger, Fighting Poverty and Reducing Welfare Dependency, in Welfare POLICY fOR the 1990s 41, 57 (Phoebe H. Cottingham \& David T. Ellwood eds., 1989) [hereinafter WeLfare Policy]. The Census Bureau data do not measure whether the same persons remain poor from year to year.

183. For example, nearly a quarter of AFDC recipients, among the poorest of the poor, stay on welfare for ten or more years. Douglas J. Besharov, Targeting Long-Term Recipients, in WeLfare PoLICY, supra note 182, at 146, 151. But see Joel F. Handler, "Ending Welfare As We Know It"Wrong for Welfare, Wrong for Poverty, 2 GEo. J. ON Fightang Poverty 3, 13-15 (1994) (arguing that the welfare population is "very dynamic").

184. In addition, several commentators suggest that poverty is not merely an economic status but also a cultural experience. For example, Professor Edgar Cahn defines poverty as not merely "deprivation of the basic necessities of hfe" but "also powerlessness: being trapped, relegated to a status from which one cannot escape, impotent to change circumstances that affect one's fate and unable to alter the conduct of others that impacts adversely on oneself, one's family, one's neighborhood." Edgar S. Cahn, Reinventing Poverty Law, 103 Y ALE L.J. 2133, 2135 (1994). To the extent that poverty shapes one's personal identity, the social meaning of poverty may transcend a narrow, economic definition. If so, poverty may influence one's outlook long after his or her economic status changes.

In addition, the effects of poverty may include lasting physical and mental harm. Medical experts agree that adequate nutrition during the first three years is critical to a child's development. Barbara Vobejda, 6 Million of Nation's Youngest Children Face Developmental Risks, WASH. Post, Apr. 13, 1994, at A3. Nutritional deprivation in toddlers frequently results in permanent damage, including stunted growth, reduced cognitive and memory capacity, mental retardation, disease, or dcath. Stephen Loffredo, Poverty, Democracy, and Constitutional Law, 141 U. PA. L. Rev. 1277, 1322 (1993); see also Handler, supra note 183, at 9 (noting that brain dysfunction in poor children often results in early school failure, which, in turn, "is one of the strongest predictors of adolescent problems including violent behavior"). Thus, economic deprivation can become a self-fulfilling prophecy; it can rob the poor, especially the young, of the tools they necd later in life to escape from poverty. At present, approximately one quarter of America's infants and toddlers live in poverty. Vobejda, supra, at A3.

185. Kevin Phimlips, The Polmics of Rich AND Poor 8-14 (1990). Note that the composition of some groups that courts have held distinctive also fluctuates over time. See infra note 260 and accompanying text.

186. Danziger, supra note 182 , at 57, 58 n.d (citing T. Adams \& G.J. Duncan, The Prevalence and Correlates of Persistent Urban Poverty (1987)).

187. Id. at 58.

188. Handman, supra note 18, at 209 (paraphrasing court's assertion in United States v. McDaniels, 370 F. Supp. 298, 307 (E.D. La. 1973), aff'd sub nom. United States v. Goff, 509 F.2d 825 (5th Cir.), cert. denied, 423 U.S. 857 (1975)). 
seeming intractability of poverty in American society. ${ }^{189}$ Many argue that poverty is the result not simply of individual or political choice, but also of political and economic structures that systematically exclude poor people. ${ }^{190}$ Some social scientists suggest that "[t]he only true solution to this problem-an mclusive and democratic politics that fully enfranchises all citizens regardless of economic station-would require fundamental social and political transformations." "191 At present such changes appear unlikely. Therefore, at least in the short run, poverty appears to be an intractablealthough not necessarily irreversible-social condition. It seems likely that America will have a sizeable population of poor people for the foreseeable future. The fact that the impoverishment is not static from year to year does not justify a conclusion that the poor as a group are insignificant, or that one who is presently poor does not possess unique attributes that may be valuable in the jury context.

\section{Community of Interest}

Some courts have decided that the poor are not a distinctive group for jury selection purposes because they do not possess a unique "community of imterest."192 A community of imterest is a shared quality or common attribute that distinguishes members of a group from the rest of the jury pool. According to this doctrine, meinbers of a group have a community of interest if they share a basic similarity of attitudes, ideas, or outlook.

The McDaniels court, for example, rejected the claim that the poor share a basic similarity in attitudes, ideas, or outlook. ${ }^{193}$ This Section

189. See, e.g. David S. Liederman, Repair the Safety Net, But Don't Remove It, Wash. Times, Feb. 13, 1995, at 20 (suggesting that the Republicans' proposed "Personal Responsibility Act" will not effectively combat poverty); Jack Sirica, A Welfare Reform Primer, NEwsdAY, Mar. 5, 1995, at A22 (stating that the percentage of the population on welfare has remained roughly constant since the 1970s). Of course, these critics do not agree as to the reasons for poverty's persistence. See generally Lawrence M. Mead, The New Polmics of Poverty: The Nonworking POOR in America (1992) (arguing that the plight of the nonworking poor is due primarily to private choice, rather than to barriers in the job market); Richard A. Posner, Economic ANalysis OF The LAw 441-44 (3d ed. 1986) (arguing that attempts to reduce poverty by redistributing wealth to the poor fail because they remove the incentive to work). But see Harry J. Holzer, Income and Social Security and Substandard Working Conditions, 47 Indus. \& LAB. REL. REv. 338 (1994) (reviewing MEAD supra) (arguing that "Mead is too quick to dismiss problems of [racial prejudice], skill deficiency, distance from job locations, and overall job availability in the labor market.").

190. See, e.g., Loffredo, supra note 184, at 1281-82 (1993) (arguing that "[w]hile the convergence of political and economic power marginalizes the poor from democratic processes, the myth of political equality simultaneously serves as a justification for denying them the heightened judicial protection that constitutional doctrine has elsewhere aceorded politically powerless minorities and other suspect classes.").

191. See, e.g., id. at 1284. But see Thomas Ross, The Rhetoric of Poverty: Their Immorality, Our Helplessness, 79 GEO. L.J. 1499, 1509 (1991) (challenging the notion that poverty is "an inescapable societal tragedy that we are helpless to remedy").

192. See, e.g., United States v. McDaniels, 370 F. Supp. 298, 308 (E.D. La. 1973), aff'd sub nom, United States v. Goff, 509 F.2d 825 (5th Cir.) cert. denied, 423 U.S. 857 (1975).

193. See, e.g., id. Ironically, American public discourse often stigmatizes the poor along precisely these lines, accusing them of being morally different from the rest of society. See, e.g., MichaEL B. 
argues that the underlying inquiry is inpossibly arbitrary. Assessing whether inembers of the group share a "basic similarity" of attitudes, ideas, or outlook is decontextual, vague, and arguably irrelevant. ${ }^{194}$ For example, soine groups that courts consider distinctive for jury selection purposes lack a common perspective or agree only in very vague terms.

Consider woinen, for example. While detailed examination of feminist legal theory is beyond the scope of this Comment, a brief glance at the literature reveals a pervasive skepticisin about essentialism-the notion that neinbers of a group share a common, abstract, self-defining perspective. ${ }^{195}$ In other words, while feminists may agree that woinen have a unique coinmunity of interest, they do not agree on whether woinen share a common outlook or similar attitudes and ideas. At the nost basic level, feminists generally accept the notion of gender difference. In the words of Professor Joan Williams, "Inen as a group differ fronı women as a group not only on the basis of biological 'sex' differences, but on the basis of social 'gender' differences."196 However, feminist legal scholars do not agree about the precise nature and scope of these differences. Rather, there is a "deep split among American feminists" about the lines of deinarcation between "sameness" and "difference."197

The writing of Carol Gilligan is illustrative. Professor Gilligan argues that women and men have different norms, such that women tend to reason in "a different voice."198 She niamtains that woinen focus on relationships and interdependence, tend to think contextually, and subordinate achievement to care. ${ }^{199}$ In contrast, nien focus on individual achievernent, tend to think abstractly, and subordinate relationships to rules. ${ }^{200}$ Gilligan suggests that classic liberalisin is founded on the nrale norm of self-interested indi-

Katz, The Undeserving Poor: From the War on Poverty to the War on Welfare 6-7 (1989) (describing the widely held view that "[p]oor people think, feel, and act in ways unlike middle-class Americans. Their poverty is to some degree a matter of personal responsibility, and its alleviation requires personal transformation, such as the acquisition of skills, commitment to the work ethic, or the practice of chastity.").

As troubling as these stereotypes may be, they have important implications for jury selection. If we believe the assumptions underlying the popular rhetoric-that the poor are as a group morally, intellectually, or motivationally different from the "middle class"--then it follows that the poor share a community of interest for jury selection purposes. Moreover, unless the jury pool inciudes the poor, juries will not benefit from their unique perspective. Therefore, if jury pools seek to represent a fair cross section of the community, they must include prospective jurors who are poor.

194. What should matter is whether members of the group share attitudes that would enrich jury deliberations. See infra Part IV.

195. I borrow the term "essentialism" from Professor Angeia Harris. Angela P. Harris, Race and Essentialism in Feminist Legal Theory, 42 STAN. L. REv. 581, 585 (1990) (challenging "the notion that a unitary, 'essential' women's experience can be isolated and described independently of race, class, sexual orientation, and other realities of experience").

196. Joan C. Williams, Deconstructing Gender, 87 Mich. L. Rev. 797, 800 (1989).

197. Id. at 798 .

198. Carol Gliligan, In a Different Votce 24-105 (I982).

199. Id. at $170-71$.

200. Id. at $18-19$. 
vidualism. ${ }^{201}$ Meanwhile, relational norms-which Gilligan identifies as the female perspective-tend to be devalued.

Some scholars reject Gilligan's central premise: the existence of a female perspective. For example, Catharine MacKinnon argues that what Gilligan identifies as norms do not really belong to women. Instead, they are the norms that "male supremacy has attributed to [women] for its own use."202 Professor MacKinnon equates difference with dominance; she describes gender as a system of power relations. ${ }^{203}$ Therefore, MacKinnon rejects any attempt to define a "women's perspective," at least while the power disparity between women and men persists. To do otherwise, MacKinnon argues, would be to legitimate the perspective that men have forced on women, thus "affirm[ing] the qualities and characteristics of powerlessness." 204

Some other feminist legal scholars, while not denying the existence of women's "different voice," reject Gilligan's formulation of that voice. For example, Robm West believes that women have a "true nature"20s and accepts that women's lives tend to be "profoundly relational."206 But, while Gilligan asserts that wonen's norms stem from social construction, West argues that biological roles-childbearing in particular-shape "women's experience." Professor West suggests that "the central insight of feninist theory of the last decade has been that women are "essentially connected,' not 'essentially separate,' from the rest of human life, both materially, through pregnancy, intercourse, and breast-feeding, and existentially, through the moral and practical life."207

Still otler feminist scholars believe that women do not liave $a$ "different voice" but several different voices. Professor Angela Harris rejects the notion that all women-regardless of class, race, sexual orientation, or "other realities of experience"208 - share a common, unitary sense of "self."209 Gender essentialism, Harris argues, ignores and niargmalizes "the same voices silenced by the mamstream legal voice," including those of black women. ${ }^{210}$ In short, she rejects the notion that "the diversity of

201. See Williams, supra note 196 , at $800,812-13$.

202. Catharine A. MacKinnon, Femmism Unmodified 38-39 (1987).

203. Id. at $32-42,39$ (arguing that "the damage of sexism is real, and reifying that into differences is an insult to [women's] possibilities."); see also Catharine A. MacKinnon, Feminism, Marxism, Method, and the State: Toward Feminist Jurisprudence, 8 Sions 635, 638 (1983) (describing male dominance as "perhaps the most pervasive and tenacious system of power in history").

204. MacKinNon, supra note 202 , at 39.

205. Robin L. West, Jurisprudence and Gender, 55 U. CH. L. Rev. 1,4 (1988).

206. Robin L. West, The Difference in Women's Hedonic Lives: A Phenomenological Critique of Feminist Legal Theory, 3 WIs. Women's L.J. 81,140 (1987).

207. West, supra note 205, at 3.

208. Harris, supra note 195, at 585.

209. Id. at 603 (challenging Professor West's conception of the biologically determined female "self").

210. Id. at 585 . 
women's experience" can be distilled to a single "essential female self."211 Instead, Harris calls for a "post-essentialist feminism"212 that incorporates the "multiple consciousness"213 of previously silenced women. ${ }^{214}$

Roughly summarized, feminist legal scholars agree that they disagree. Those who believe in the notion of an "essential" women's perspective dispute what it is. Others are wary of essentiahist claims altogether. ${ }^{215}$ The range of women's experience is simply too diverse to yield any single, overarching perspective. As Deborah Rhode warns, "[e]fforts to provide the 'woman's poimt of view' . . . risk contributing to their own marginalization." 216

What lesson does feminist legal theory provide for courts considering whether a particular group is distinctive for jury selection purposes? Courts have construed the requirement that distinctive groups must have a "basic similarity in attitude, ideas, or outlook" too strictly. To the extent that women share a "basic similarity" of perspective, it is only on a very general level. Even a quick ghimpse at the work of feminist legal theorists reveals a rich variety of perspectives, imsights, and agendas. Although Deborah Rhode has articulated some areas of shared "commitments" among feminist critical theorists, she agrees that there is no "unifying Grand Theory."217 Reduced to its core, feminist legal scholars share an understanding that gender matters. ${ }^{218}$

Nevertheless, it would be unthinkable today to claim that a jury pool that excluded women could represent a fair cross section of the community. Why? Because the presence of women jurors is critical to the operation and

211. Id. at 615 .

212. Id. at 610 .

213. Id. at 615 (citing Mari J. Matsuda, When the First Quail Calls: Multiple Consciousness as Jurisprudential Method, 11 Women's RTs. L. REP. 7, 9 (1989)).

214. See also Deborah L. Rhode, Feminist Critical Theories, 42 Stan. L. Rev. 617, 619 (1990) (calling for "multiple [legal] frameworks that avoid universal or essentialist claims and that yield concrete strategies for social change").

215. But see Martha Minow, Feminist Reason: Getting It and Losing It, 38 J. Legal Educ. 47, 51 (1990) (arguing that "[c]ognitively, we need simplifying categories, and the unifying category of 'woman' helps to organize experience, even at the cost of denying some of it.").

216. Rhode, supro note 214 , at 618.

217. Id. at 619 (identifying the following three "central commitments" of feminist critical theories: "On a political level, they seek to promote equality between women and men. On a substantive level, feminist critical frameworks make gender a focus of analysis; their aim is to reconstitute legal practiees that have excluded, devalued, or undermined women's concerns. On a methodological level, these frameworks aspire to describe the world in ways that correspond to women's experience and that identify the fundamental social transformations neeessary for full equality between the sexes.").

218. 1 derive this idea from Deborah Rhode, who claims that "[f]eminism takes gender as a central category of analysis." Id. at 617-18. However, given the breadth and sophistication of the literature in this field, any generalization is dangerous. Note that this Comment does not aim to criticize feminist critical theory for a lack of consensus. On the contrary, the work of feminist legal scholars offers valuable insights into the issue of what constitutes a sufficiently coherent group for purposes of the distinctiveness test. 
the legitimacy of the justice system. ${ }^{219}$ Everyone agrees that the presence of women on juries promotes the interests of the trial participants, the cominunity, and the jury itself. However, the foregoing discussion demonstrates that it is exceedingly difficult to identify a single "women's perspective." Woinen differ from one another politically, socially, economically, racially, and morally. Judicial recognition that women are a distinctive group, despite this diversity, illustrates the mability of the community of interest test to distinguish meaningfully between distinctive and nondistinctive groups.

More generally, the community of interest test proceeds from unrealistic assuniptions about the complexity of human association. In real life, each person is a inember of many groups sinnultaneously. Group identities frequently overlap, and the distinctions between different groups blur and fade. Therefore, it would be highly artificial for courts to require that a distinctive group have anything but the most basic similarity in attitude, ideas, or outlook. On a practical level, however, such a loose standard provides insufficient guidance about how courts should decide which groups are distinctive for jury selection purposes. Put simply, this standard provides no ineaningful basis to differentiate among the literally thousands of possibly distinctive groups: commercial fishermen, Oakland Raiders fans, Lithuanian Americans, and so on.

Another inajor problein with the community of interest requirement is that it is decontextual. Courts sinply evaluate whether the members of a particular group share a basic similarity in attitudes, ideas, or outlook. This inquiry is highly abstract and it leads to subjective implementation. As a result, the test is poorly tailored for the task of identifying distinctive groups relevant to jury selection. Some groups that are critical to the legitimacy of the jury process, such as women, do not have a single outlook. Other groups that share a common perspective, such as Red Sox fans, may be irrelevant to the fairness and impartiality of a jury. ${ }^{220}$ Therefore, the present test is overimclusive with respect to some groups, and vastly underinclusive with respect to others.

In other words, the current doctrinal test fails to distinguish between shared attitudes that are relevant to jury service and those that are not. For example, a juror's attitude toward the fairness of the crimmal justice system and its participants may be crucial to the way she evaluates testimony and

219. See Ballard v. United States, 329 U.S. 187, 193-94 (1946) (holding that women are a distinctive group, even though they do not share a common attitude as a "class," because "a distinct quality is lost if either sex is excluded" from jury service).

220. Even the most dedicated Red Sox fan would probably admit that one could compile an impartial jury-which the Supreme Court defines as a group of jurors who will conscientiously apply the law and find the facts-without regard to baseball allegiance. See Lockhart v. McCree, 476 U.S. 162,178 (1986) (defining an impartial jury). 
evidence, deliberates, and reaches a verdict. ${ }^{221}$ By contrast, a juror's baseball allegiance may have little importance in the jury chambers. Because the current doctrinal test fails to link the community of interest requirement to criteria relevant to jury selection, the doctrine fails to achieve its goal of fair and representative juries. Courts do not consider distinctive some groups whose members would enhance the spectrum of perspectives in jury deliberations; meanwhile, they find other groups distinctive for reasons that have nothing to do with their ability to contribute to deliberations. This is a troubling result.

\section{Discrimination}

Some courts have declined to recognize the poor as a distinctive group on the ground that they do not suffer from societal "discrimination and prejudice."222 More broadly, these courts have suggested that no group can qualify as distinctive without a showing of societal discrimination. 223 There are two principal flaws in this approach. First, discrimination and prejudice do not have simple, uniformly accepted meanings. Instead, these terins are vague and malleable. If courts interpret the terns broadly, almost all groups are victims of systemic "discrimination." If courts interpret the terms too narrowly, groups that are vital to the legitimacy of the jury process may flunk the doctrinal test. ${ }^{224}$ Second, this inquiry conflates the question of distinctiveness under the Sixth Amendment with suspect-class status under the Fourteenth Amendment.

\section{Discrimination Against the Poor}

Some courts have concluded that the poor have not suffered societal discrimination. ${ }^{225}$ Yet under almost any objective definition of the term, the poor are victims of societal prejudice. ${ }^{226}$ For example, Americans frequently characterize the poor as "lazy and shiftless"227 or as "patently

221. See Zeigler, supra note 3 , at 1076-77 (discussing a survey that examined attitudes among different age groups regarding the justice system).

222. See, e.g., Anaya v. Hansen, 781 F.2d 1, 6 (1st Cir. 1986).

223. See, e.g., id.; Barber v. Ponte, 772 F.2d 982, 999 (lst Cir. 1985) (suggesting that distinctive status should apply only to groups needing "special protection" because they have been the victims of societal discrimination), cert. denied, 475 U.S. 1050 (1986).

224. A related concern is that this test is decontextual. In other words, under the current formulation of the test, courts inquire in the abstract whether members of the group suffer from discrimination and prejudice without regard to whether judicial recognition of the group will advance the purposes of the fair cross-section doctrine. See infra Part IV.

225. See, e.g., Anaya, 781 F.2d at 6.

226. By "prejudice" I mean the "endorsement or acceptance of the content of a negative cultural stereotype." Jody Armour, Stereotypes and Prejudice: Helping Legal Decisionmakers Break the Prejudice Habit, 83 CALIF. L. REv. 733, 742 (1995) (citing Margo J. Monteith et al., Prejudice and Prejudice Reduction: Classic Challenges, Contemporary Approaches, in Sociaz Cognition: ImPact on Social Psychology 323, 333-34 (Patricia G. Devine et al. eds., 1994)).

227. Loffredo, supra note 184, at 1319 (discussing this stereotype) (citations omitted). 
immoral or socially deviant."228 Society accuses them of embracing poverty by choice, ${ }^{229}$ and they have become "an underclass, dehumanized and demomized in the public's mind."230 Increasingly, we identify the poor as the source of our nation's problems, as well as their own. ${ }^{231}$ Professor Thomas Ross suggests that American culture has succumbed to a "rhetoric of poverty": we assert that the poor are conceptually different from other citizens and conclude that society cannot solve the problems that spring from the poor's own moral degeneracy. ${ }^{232}$

In addition to this prejudice, the poor confront a less obvious, yet no less harmful, form of societal discrimination. American society inextricably links privilege and wealth. ${ }^{233}$ If wealth corresponded with individual inerit, ${ }^{234}$ the present state of affairs might not cause concern. However, critical legal theorists suggest that "decontextualized, objective definitions of individual merit" are not truly neutral. ${ }^{235}$ Instead, inany seeiningly objective definitions of merit tend to disadvantage those who lack

228. Ross, supra note 191, at 1507 (describing negative views of the poor).

229. See, e.g., George Will, Soft Voice in a Deadly Crisis, WAst. Post, June 19, 1994, at C7 (arguing that "a poverty of inner resources" is to blame for the welfare crisis).

230. Loffredo, supra note 184, at 1318 (citations omitted); see also Ross, supra note 191, at 1507 (criticizing the "myth of the welfare mother with a Cadillac" and popular depictions of the poor as "hostile street criminals who terrorize most cities," or as "traumatized drunks, drifters, homeless shopping-bag ladies and released mental patients who frequently roam or collapse on city streets") (citations omitted).

231. Consider, for example, the characterization of "welfare mothers" in the present debates about welfare reform.

232. Ross, supra note 191, at 1499, 1513-15.

233. Admittedly, my characterization of the relationship between wealth and "privilege" is overly simplistic. In fact, there is considerable overlap between the privileges of color and class in American society. For example, the Census Bureau reports that in 1988 the median net worth of white families was more than ten times that of black families. Dwight L. Greene, Justice Scalia and Tonto, Judicial Pluralistic Ignorance, and the Myth of Colorless Individualism in Bostick v. Florida, 67 Tur. L. Rev. 1979, 1988 n.22 (1993) (citing Bureau of the Census, U.S. Dep't of Commerce, Current Population Reports, Household Economic Studies, SERIES P-70, No. 22, Household Wealth AND ASSET OWNERSHIP: 1988, at 9 (1990) (reporting that the 1988 median household net worth was $\$ 43,279$ for whites and only $\$ 4,169$ for blacks)); see also Number of Poor in U.S. Is Highest in 33 Years, THE GazETTE (Montreal), Oct. 7, 1994, at A10 (stating that, according to the Census Bureau's 1993 poverty report, $33.1 \%$ of black Americans live below the federal poverty line, while the poverty rate among whites is only $12.2 \%$ ). Unfortunately, an examination of the relationship between race and class is beyond the scope of this Comment.

234. By "individual merit" I mean something that entitles a person to a benefit as a mattcr of theoretieal, intrinsic right. Of course, culture determines the definition of individual merit. 1t is what members of the society aspire to reward. I contrast individual merit with the tcrm "social attributions of merit." The latter term describes those attributes, behaviors, or circumstanees that society actually rewards. In other words, society may think it rewards individual merit, when in fact it rewards social attributions of merit.

235. Greene, supra note 233, at 1987; see, e.g., Richard Delgado, Affirmative Action as a Majoritarian Device: Or, Do You Really Want to Be a Role Model?, 89 Mrch. L. Rev. 1222, 1224-25 (1991) (arguing that current societal standards of merit perpetuate white supremacy); Gary Peiler, Race Consciousness, 1990 DuKE L.J. 758, 777-78 (contending that current standards of merit are not objective, but favor whites). 
wealth. ${ }^{236}$ To the extent that society allocates benefits according to social attributions of merit that lack predictive or explanatory power, it disadvantages groups that do not possess "merit" relative to those groups that do. This result constitutes a form of societal discrimination.

Professor Dwight Greene offers an informative example. ${ }^{237}$ Assume that $\mathrm{X}$ and $\mathrm{Y}$ attend the same high school and undergraduate institution. Both take the same classes and graduate with the same grade point average. After college, $\mathrm{X}$ and $\mathrm{Y}$ both decide to apply to law school. They receive identical scores on the LSAT, and both enroll at Boalt Hall. As first year law students, $\mathrm{X}$ and $\mathrm{Y}$ take the same courses, taught by the same professors. Unable to find rent-controlled apartments in Berkeley, both students decide to live in Oakland. While $\mathrm{X}$ can afford to own a car, $\mathrm{Y}$ cannot. $\mathrm{Y}$ commutes to school by a combination of walking and public transportation. As a result, $Y$ spends an additional two hours each day, five days per week, commuting to and from school. Assuming that neither student is able to study during her commute, at the end of a fifteen week semester $\mathrm{X}$ has 150 more hours available to study than Y.

Assuming that there is a causal relation between the time one spends studying and the grades one receives in law school, $X$ enjoys a relative advantage over $Y$. Although this example is trivial, it illustrates the difficulty of defining individual merit. As Professor Greene suggests, "the grades these two students received may not reflect their relative merits as much as their relative economic statuses." ${ }^{\text {"38 }}$ One might argue that, if $\mathrm{X}$ studies more than $\mathrm{Y}$ she deserves higher grades, as a matter of individual merit. However, grades may actually reward social attributions of merit, not individual merit itself. ${ }^{239}$ As this hypothetical demonstrates, law school grades might favor the economically privileged over the less fortunate.

Professor Greene's example illustrates a larger point. Regardless of the "objective" criteria we use-standardized test scores, educational attainment, job status, community involvement-decontextualized social attributions of merit do not necessarily reflect individual merit. ${ }^{240}$ Critical Legal Scholars argue that abstract conceptions of merit tend to favor the status quo. ${ }^{241}$ Therefore, a system that allocates rewards and benefits according to these criteria tends to discrimmate against-or at least subordinate-those who are nonprivileged, mcluding women, people of

236. Greene, supra note 233 , at 1987-88.

237. This hypothetical is a modified version of one first presented by Professor Greene. Id.

238. Id. at 1987.

239. See Kimberle W. Crenshaw, Foreword: Toward a Race-Conscious Pedagogy in Legal Education, 11 NAT'z BrACK L.J. 1, 9-10 (1989) (discussing the alienation of minorities in the classroom).

240. See Greene, supra note 233, at 1987.

241. E.g., id; Kimberle W. Crenshaw, Race, Reform and Retrenchment: Transformation and Legitimation in Antidiscrimination Law, 101 HARv. L. REv. 1331, 1380 (1988) (arguing that an "unspoken" social norm exists and that this "norm-although no longer explicitly white supremacistremains, nonetheless, a white norm"). 
color, and the poor. This example suggests that society may not allocate social rewards according to individual merit, but according to economic privilege (or other social attributions of merit). If so, the poor are victims of an ingrained social bias that we may loosely describe as discrimination. The courts' failure to recognize this problem illustrates the subjective nature of the discrimination test and its inability to provide a meaningful distinction between distinctive and nondistinctive groups.

\section{Conflation of Sixth Amendment and Fourteenth Amendment Inquiries}

A second major flaw in the discrimination analysis is that it conflates two distinct imquires: "distinctiveness" under the Sixth Amendment with "suspectness" under the Due Process Clause of the Fourteenth Amendment. ${ }^{242}$ The Sixth and Fourteenth Amendments protect different interests, and therefore are not interchangeable. ${ }^{243}$ The Equal Protection Clause of the Fourteenth Amendment concerns "equality and even-handedness in governmental action."244 The Sixth Amendment, on the other hand, concerns the integrity and legitimacy of the criminal justice system. ${ }^{245}$ While these interests may frequently overlap, they are certainly not identical.

In the equal protection context, courts have held that a class is suspect if government actors have singled out the class for disparate treatinent. ${ }^{246}$ In the Sixth Amendment context, by contrast, courts should identify a group as distinctive if judicial recognition of the group will promote the purposes of the fair cross-section doctrine-protecting the interests of criminal defendants, the community, and democratic government. ${ }^{247}$ Given these distinctions, courts should not apply the same doctrinal test to determine whether a group is distinctive under the Sixth Amendment and whether it is suspect under the Equal Protection Clause of the Fourteenth Amendment.

Several commentators have noted that it should be easier to prove a fair cross-section violation than an equal protection violation because the latter requires a showing of discriminatory intent while the former does

242. Zeigler, supra note 3 , at 1062 (suggesting that what motivates judicial decisions about distinctiveness "may be [the courts'] confusion of the concepts of cognizability and suspectness"); $i d$. at 1064 (argning that "to date, courts have treated cognizability in much the same manner in sixth amendment and equal protection cases").

243. But see Zeigler, supra note 3, at 1065 (claiming that "since designations of cognizability serve essentially the same interests whether the source of the cross-sectional right is the equal protection clause or the sixth amendment, the courts have properly used the cases based on these two constitutional provisions interchangeably for cognizability purposes").

244. See, e.g., Lawrence H. Tribe, American Constitutional Law 1436 (2d ed. 1988).

245. See supra text accompanying notes $15,112$.

246. See, e.g., Hemandez v. Texas, 347 U.S. 475,478 (1954) (holding that a group is cognizable under the Fourteenth Amendment if "the laws, as written or as applied, single out that class for different treatment not based on some reasonable classification").

247. Lockhart v. McCree, 476 U.S. 162, 174-75 (1986). 
not. ${ }^{248}$ As a result, certain groups that are not suspect classes under the Fourteenth Amendment's Equal Protection Clause may be distinctive for purposes of the Sixth Amendment's fair cross-section requirement.

Take white males, for example. Assume that $54 \%$ of the adults eligible for jury service in a particular federal district are white men. ${ }^{249}$ In the twenty-four inonths immediately prior to the defendant's trial, only $26.7 \%$ of those summoned for the jury wheel are white males. Over the same twenty-four month period, white men coinpose only $14 \%$ of the actual, post-summons venire. The judge selects the defendant's jury froin a panel of fifty-three people, of whom five, or $9.4 \%$, are white men. Finally, assume there is no evidence of intentional discrimmation by jury officials. Is the defendant's jury drawn from a fair cross section of the community? Of course not.

In the hypothetical, the defendant's venire underrepresents white males by $44.6 \%{ }^{250}$ During the two years preceding the defendant's trial the average rate of underrepresentation is $39.5 \%{ }^{251}$ Based on these statistics, the defendant should be able to make a prina facie showing of a fair crosssection violation. Yet, if we accept the First Circuit's rationale in Anaya, the hypothetical venire is presumably constitutional; white inales are not a subordinated group and thus presumably are not cognizable for jury selection purposes. Does this result make sense? Not if the underlying purpose of the fair cross-section guarantee is to ensure that the venire broadly represents the community in which the trial occurs.

\section{IV \\ ReCONSIDERING THE DisTINCTIVENESS DOCTRINE}

As Part III denionstrates, the doctrinal test for identifying distinctive groups requires courts to evaluate vague, ill-defined factors that do not convincingly distinguish such groups froin other groups in society. As a result, judges currently lack a principled basis for determining whether a particular group is cognizable, absent proof of intentional discrimination by jury officials. $^{252}$

Assuming that the current test is meffective, what test should the courts apply? In Lockhart v. McCree, ${ }^{253}$ the Supreme Court stated that "we

248. See, e.g., Magid, supra note 107, at 1090-91.

249. This hypothetical is based upon the facts of Duren v. Missouri, 439 U.S. 357 (1979), in which the general venire underrepresented women by $39.5 \%$ and the defendant's venire underrepresented them by $44.6 \%$.

250. $54 \%$ less $9.4 \%=44.6 \%$ discrepancy between venire eligibility and venire representation.

251. $54 \%$ less $14.5 \%=39.5 \%$ discrepancy between venire eligibility and venire representation.

252. See Barber v. Ponte, 772 F.2d 982, 1000 (Ist Cir. 1985) (stating that when jury officials intentionally exclude individuals or groups from jury service, they effectively create a judicially cognizable group), cert denied, 475 U.S. 1050 (1986); see also Zeigler, supra note 3, at 1062 (noting that "[i]n cases of admitted, intentional discrimination, jury officials 'define' the excluded group by their statements and actions").

253. 476 U.S. 162 (1986). 
think it obvious that the concept of 'distinctiveness' must be linked to the purposes of the fair-cross-section requirement."254 To reiterate an important point, the Court identified three such purposes: (a) to guard against the arbitrary exercise of prosecutorial authority; (b) to preserve "public confdence $m$ the fairness of the criminal justice system"; and (c) to promote shared responsibility for the administration of justice as a "phase of civic responsibility."25s Stated more broadly, the fair cross-section requirement serves the interests of individual litigants, the community, and democratic government. ${ }^{256}$

This Part proposes an alternative test for distinctiveness based on the Lockhart rationale. First, as a matter of admimistrative necessity, the group must be judicially identifiable. Next, courts should evaluate whether judicial recognition of the group would advance the purposes of the fair crosssection doctrine. Courts should recognize as distinctive any group satisfying both elements of this approach. This Part employs this alternative test to argue that judicial recognition of the poor as a distinctive group would advance the interests of individual hitigants, the community, and democratic government.

\section{A. Identifiability}

As demonstrated above, the poor are an identifiable group. Since the 1960 s, the federal government has used the poverty line to distinguish between the poor and the nonpoor. Although the poverty line is not a perfectly precise boundary, Part III demonstrated that many groups currently recognized as distinctive are much nore difficult to delineate. Race and ethnicity, for example, involve a complicated mix of objective criteria and subjective factors. ${ }^{257}$ Despite these difficulties, courts have held many racial and ethnic groups cognizable. ${ }^{258}$ The poor, in contrast to these groups, are relatively easy to identify and define. Annual income provides a simple, objective yardstick by which to measure the group. Moreover,

254. Id. at 174 .

255. Id. (citing Taylor v. Louisiana, 419 U.S. 522, 530-31 (1975)).

256. See generally Roger S. Kuhn, Jury Discrimination: The Next Phase, 236 S. CAL. L. REv. 235, 241-49 (1968) (arguing that impartial juries benefit various participants in the justice system); Toni $M$. Massaro, Peremptories or Peers?-Rethinking Sixth Amendment Doctrine, Images, and Procedures, 64 N.C. L. REv. 501, 512 (1986) (arguing that broad popular participation on juries allows the community conscience to influence the trial process).

257. Ford, supra note 165 , at 1239; see also supra notes 166-178 and accompanying text.

258. In fact, courts have recognized that any attempt to define a large class of people inevitably involves an element of subjectivity. Zeigler, supra note 3, at 1073 (citing United States v. Butera, 420 F.2d 564, 570 (1st Cir. 1970) (holding that although young adults eomprised an "ill-defined" category, the requirement of a "distinct group" cannot be "applied so stringently . . that possible discrimination against a large class of persons-in our case, those between 21 and 34-will be insulated from attack"), overruled, Barber v. Ponte, 772 F.2d 982 (1985), cert. denied, 475 U.S. 1050 (1986)). For purposes of this Comment, it suffices to say that the poor are not harder to identify than groups detcrmined by reference to race or ethnicity. This begs the question, of course, of whether the present test for identifiability makes sense. I leave that question for another day. 
most citizens already calculate their annual incoine on their tax returns. Therefore, defining the poor in terms of annual income is both sensible and administratively feasible.

Although the coinposition of the poor changes from one year to the next, courts have overeinphasized this problem. Over the past several decades, the poor have remained a relatively stable group within the population. ${ }^{259}$ In addition, the problem of changing composition is not unique to the poor. For example, some courts have held certain religious groups to be cognizable, ${ }^{260}$ despite the fact that people often change religious affiliations. Likewise, the fact that the poor are not a totally static group should not preclude their recognition as a distinctive group.

Thus, it seeins fair to conclude that the poor are an identifiable group. As the next step in this alternative distinctiveness test, I consider whether judicial recognition of the poor would advance the purposes of the fair cross-section doctrine.

\section{B. Advancing the Purposes of the Fair Cross-Section Doctrine}

\section{Litigants' Interests}

One fundamental purpose of the criminal jury is to "guard against the exercise of arbitrary power."261 The jury accomphshes this role by interposing the "commonsense judginent" of the community between the criminal defendant and the government actors who run the criminal justice system. ${ }^{262}$ Under this rationale, the judgnient of laypeople serves as a "hedge against the overzealous or mistaken prosecutor,"263 the corrupt pohice officer, or "the compliant, biased, or eccentric judge."264 In short, the jury protects the interests of criminal defendants ${ }^{265}$ by empowering

259. See supra notes $182-188$ and accompanying text.

260. See, e.g., U.S. v. Gelb, 881 F.2d 1155, 1161 (2d Cir. 1989) (holding that members of the Jewish faith are a distinctive group).

261. Taylor v. Louisiana, 419 U.S. 522, 530 (1975) (citing Duncan v. Louisiana, 391 U.S. 148, 155-56 (1974)). See Williams v. Florida, 399 U.S. 78, 100 (1970) (holding that the purpose of the jury is "to prevent oppression by the Government"); Johnson v. Louisiana, 406 U.S. 356, 373 (1972) (holding that juries provide a safeguard against arbitrary law enforcement).

262. Williams, 399 U.S. at 100 (holding that "the essential feature of a jury obviously lies in the interposition between the accused and his accuser of the common-sense judgment of a group of laymen, and in the community participation and shared responsibility that results from that group's determination of guilt or innocence').

263. Taylor, 419 U.S. at 530.

264. Duncan v. Louisiana, 391 U.S. 148,156 (1968).

265. Most of the Supreme Court's fair cross-section cases involve challenges by criminal defendants under the Sixth Amendment. Therefore, this Comment primarily discusses criminal juries. However, civil litigants have the same interests in jury composition as criminal defendants. See, e.g., Kuhn, supra note 256, at 244 (arguing that "[t]he interests of civil litigants, both plaintiffs and defendants, in fairly selected juries are essentially the same as those of criminal defendants. Life and liberty may not be involved, but important property rights frequently are."); see also Thiel v. Southern Pac. Co., 328 U.S. 217, 220 (1946) (stating that "[t]he American tradition of trial by jury, cousidered in connection with either criminal or civil proceedings, necessarily contemplates an impartial jury drawn from a cross-section of the community") (emphasis added). 
ordinary citizens to oversee the administration and administrators of justice. ${ }^{266}$

According to the Supreme Court, a jury cannot perform this function properly when it draws from "only special segments of the populace or if large, distinctive groups are excluded from the pool."267 The jury's ability to reflect the "commonsense judgment" of the cominunity depends on the representativeness of the jury members. ${ }^{268}$ Justice Thurgood Marshall warned that "when any large and identifiable segment of the cominunity is excluded from jury service, the effect is to remove from the jury room qualities of human nature and varieties of human experience, the range of which is unknown and perhaps unknowable."269 In such instances, the jury does not accurately represent "the commonsense judgnient of the commumity."270

The poor constitute a substantial portion of the cominunity. According to the Census Bureau's most recent poverty report, 39.3 million Americans live below the federal poverty line, the most smce $1961 .{ }^{271}$ In 1993 alone, 1.3 million people joined the ranks of the poor, increasing the total percentage of those living below the poverty lime to 15.1 percent. ${ }^{272}$ Even still, critics argue that the federal poverty line dramatically understates the number of Americans "who cannot afford basic necessities such as food, clothing, and shelter."273 The exclusion from jury service of such a significant segment of the population calls imto question the jury's ability to express accurately the judgment of the commumity as a whole.

It is not only the number of America's poor that makes their representation on juries so vital, however. Their mclusion would also furnish a perspective that is essential to the creation of a truly impartial "community judgment." Central to the fair cross-section doctrine is a belief that "commumity judgment, realized through debate among subgroups, will not share

266. The scope and legitimacy of the jury's ability to depart from established rules, versus merely overseeing the administration of those rules, is subject to debate. See, e.g., Mortimer R. Kadish \& Sanford H. Kadish, The Institutionalization of Conflict: Jury Acquittals, 27(2) J. Soc. Issues 199, 21217,216 (I97I) (proposing that juries have authority - "always within limits"-to nullify statutory law); infra notes 32I-325 and accompanying text.

267. Taylor v. Louisiana, 4I9 U.S. 522, 530 (1975).

268. Brown, supra note 98 , at 114 .

269. Peters v. Kiff, 407 U.S. 493, 503 (plurality opinion) (Marshall, J., joined by Douglas and Stewart, JJ.).

270. Taylor, 419 U.S. at 530.

271. THE GAZETTE, supra note 233 , at A10 (stating that "[p]overty in I993 was defined as an income of $\$ 14,763$ for a family of four").

272. Id.

273. Loffredo, supra note 184, at $1316 \mathrm{nn} .170-71$ (citing JoHN E. SchwaRz \& ThOMAs J. VOLGY, ThE ForgotTen AMERICANs 61-63 (1992) (stating that in 1989, 56 million Americans, approximately one-quarter of the population, lived in functional poverty)); see also D'Vera Cohn, Undercount of the Poor is Alleged: Report Says Census is Off by a Sixth. WASH. Post, Sept. 30, 1992, at D1 (stating that, according to the Greater Washington Research Center, the 1990 Census failed to count a sixth of the District of Columbia's poor population). 
the prejudices and jaded perspectives of prosecutors or judges."274 The Supreme Court has described this principle as "diffused impartiality."275 Professor Darryl Brown asserts that this understanding of impartiality inplicitly rejects the idea "that an unbiased mdividual who acts objectively and in good faith can be a neutral arbiter, fungible with any other, regardless of social origins." 276 In addition, it presumes that the community is composed of discrete subgroups ${ }^{277}$ and that affiliation with these groups affects the outlooks of their ineinbers.

Several commentators accept the notion of diffused impartiality. Interest-group theorists and legal "realists" agree with Justice Scalia's assertion that "all groups tend to have particular sympathies and hostilities-most notably, sympathies towards their own group members."278 In fact, scientific research suggests that a juror's background is likely to influence the way she perceives and evaluates information. Jurors tend to "inold information into a plausible 'story' or 'scheina' based on their prior experiences."279 These stories are "usually derived from personal experience and 'common sense.' "280 Therefore, while no societal group possesses a single, uniforin perspective, ${ }^{281}$ each juror possesses an "interpretive bias" based on her own personal background and experience. ${ }^{282}$

The fair cross-section doctrine recognizes that individual jurors have interpretive biases, and it presumes that a jury consisting of people with different perspectives will "expose[] and check[]" these biases. ${ }^{283}$ The assumption is that "the input of several [distinctive] voices may reduce the

274. Brown, supra note 98 , at 116 .

275. Taylor v. Louisiana, 419 U.S. 522, 530-31 (1975) (quoting Thiel v. Southem Pac. Co., 328 U.S. 217, 227 (1946) (Frankfurter, J., dissenting)).

276. Brown, supra note 98, at 116. Professor Brown distinguishes between "specific bias" and "interpretive bias." Specific, or personal, bias includes familiarity with a defendant, a victim, or an attomey, exposure to media coverage, or other special sympathies toward a participant in the case. Interpretive bias arises "from the varying perspectives that jurors bring to the court even without any specific knowledge of or connection to the case." Id. at 121. Voir dire, peremptory strikes and sequestration of the jury aim to root out and eliminate personal bias. The fair cross-section doctrine attempts to counterpoise, although not necessarily eliminate, interpretive bias. Id. at 121-22.

277. See, e.g., Apodaca v. Oregon, 406 U.S. 404, 413 (1972) (recognizing that members of " "minority groups" may have distinctive viewpoints); Brown supra note 98, at 116 n.47 (same).

278. Powers v. Ohio, 499 U.S. 400, 424 (1991) (Scalia, J., dissenting).

279. Hon. B. Michael Dann, "Learning Lessons" and "Speaking Rights": Creating Educated and Democratic Juries, 68 lND. L.J. 1229, 1242 (1993) (citations omitted).

280. Irwin A. Horowitz \& Thomas E. Willging, The Psychology of Law: Integrations and APPLICATIONS 210 (1984).

281. See supra Part 1II.C.

282. Brown, supra note 98 , at $121-22$; Kuhn, supra note 256 , at 245 (stating that "[i]ndividual jurors almost always bring into the jury room individual preconceptions based on experience or prejudice'). Empirical research supports this assumption. For example, in a 1992 poll of nearly 800 people who served on criminal and civil juries $70 \%$ of black jurors disagreed that in a conflict of testimony between a law enforcement officer and a defendant a judge or jury should believe the law enforcement officer. Less than half of the white jurors shared this view. Racial Divide Affects Black, White Panelists, NAT'L L.J., Feb. 22, 1993, at S8, S9 [hereinafter NAT'L L.J.Lexis Poll].

283. Phoebe A. Haddon, Rethinking the Jury, 3 WM. \& MARY Brll RTs. J. 29, 56 (1994). 
possibility of an unfair, short-sighted, or erroneous decision."284 The doctrine further suggests that the proper role of the jury is not to discover "scientifically derivable and objective truth," but rather to exercise judgmentprimarily through dialogue and deliberation-in the face of uncertainty. ${ }^{285}$ In summary, the fair cross-section doctrine promotes the interests of litigants, particularly criminal defendants:

in our heterogeneous society jurors will inevitably belong to diverse and often overlapping groups defined by race, religion, ethnic or national origin, sex, age, education, occupation, economic condition, place of residence, and political affiliation; . . . it is unrealistic to expect jurors to be devoid of opinions, preconceptions, or even deep-rooted biases derived froin their life experiences in such groups; and hence ... the ouly practical way to achieve an overall impartiality is to encourage the representation of a variety of such groups on the jury so that the respective biases of their members, to the extent they are antagonistic, will tend to cancel each other out. ${ }^{286}$

If one accepts this rationale, it follows that the underrepresentation of poor people on jury venires undercuts the aspiration that litigants receive a fair, unbiased trial. This concern is particularly acute in the criminal trial context, given the extreme stakes involved. This concern also may be particularly important when the defendant is poor, if one accepts, as Part III suggests, that the poor frequently are the targets of general societal prejudice. Put simply, the risk of unchecked bias against poor defendants increases if the poor are not represented on jury venires. ${ }^{287}$ Moreover, if the poor don't serve on juries, otherwise unrepresented perspectives inay be lost.

Consider the following hypothetical. An eighteen-year old, unmarried, unemployed "welfare nother" is charged with theft of federal property. She rejects a plea bargain, pleads not guilty, and exercises her constitutional right to a jury trial. At trial the prosecution calls a single witness, and the defendant takes the stand in her own defense. No other evidence is introduced, so that the outcome of the case hinges on the jury's assessment of the credibility of each side's testimony.

Assume further that the racial, ethnic, and gender composition of the defendant's petit jury is roughly reflective of the community. However, each juror's family incoine exceeds $\$ 70,000$ per year. The defense offers no evidence of discriminatory intent on the part of jury officials. Voir dire

284. Massaro, supra note 256 , at 511 .

285. Haddon, supra note 283, at 56.

286. People v. Wheeler, 583 P.2d 748, 755 (Cal. 1978) (emphasis added).

287. See Zeigler, supra note 3, at 1072 (arguing that "possible partiality or bias against a defendant if members of his age group are excluded warrant a designation of eognizability'). 
reveals no evidence of lurking bias, and the attorneys do not remove any jurors for cause.

Should we feel comfortable that this jury-drawn from a venire without a single poor person-contains a "combination of differing perspectives [that] will balance out to some acceptable level of impartiality"? ${ }^{288}$ Perhaps not. One concern is that jurors might harbor subtle (even subconscious) bias against an unwed "welfare motler." A second concern is that the jurors-even if their intentions are as pure as the driven snow-lack an experiential perspective that may be relevant, or even critical, to assessing the credibility of the testimony offered at trial. ${ }^{289}$ In either event, the defendant might not receive an impartial trial.

Greater economic diversity among jurors might allay both concerns. First, the presence of poor jurors might cause fellow jurors to confront their own automatic discriminatory tendencies. Drawing on research from social and cognitive psychology, Professor Jody Armour distinguislies between one's unconscious perceptions about social groups (stereotypes) and one's conscious personal beliefs (prejudice). ${ }^{290}$ Armour argues that stereotypes can be controlled by activating controlled cognitive processes. ${ }^{291}$ In other words, a non-prejudiced person can suppress her unconscious stereotypes by conscious effort. By contrast, unless one's conscious cognitive processes are triggered, stereotypes go uncliecked. ${ }^{292}$ The presence of a poor juror in the cliambers miglit cause other jurors to cliallenge consciously their automatic stereotypes about a poor defendant, thereby enhancing the rationality of the jury's deliberation and verdict.

Second, poor jurors miglit bring unique and valuable perspectives to the jury chamber. Empirical evidence suggests a correlation between one's inconie and one's attitudes relevant to jury service. ${ }^{293}$ A compreliensive

288. Knowles \& Hickman, supra note 18, at 207.

289. Professor Jeffrey Abramson offers the following example,

In 1990, Han Tak Lee, a Korean-born defendant, was found guilty of murdering his daughter by arson. No Asian-Americans served on the jury and several jurors indicated that they were swayed by the prosecutor's emphasis on Lee's lack of emotion when firefighters led him and his grieving wife to the charred cabin where their daughter's body was recovered. Following the guilty verdict, Asian-American groups rallied in support of Lee, pointing out that "his behavior during and after the fire was inexplicable to most Americans and appeared to convey his guilt-but it was perfectly in tune with Korean custom." The Rev. Joon Soo Choe, an organizer of the rally, said that "Korean fathers, even when they are feeling extreme sorrow, they can't cry."

Jefrey Abramson, We the Jury: The Jury System and the Ideal of Democracy $101 \mathrm{n}^{*}$ (1994) (citing Jenifer Lin, Was the Jury Confused by Culture-or Did He Kill His Daughter?, PhiladelPHA INQUIRER, April 28, 1992, at AI.

290. Armour, supra note 226 , at 741-42.

291. Id. at 760-62 (citations omitted).

292. Id.

293. The following data stem from a survey conducted in Queens County, New York in I973. In Johnson v. Durante, No. 73C II59-EN (E.D.N.Y., filed Aug. 3, 1973), the plaintiff used the data to support his claim that jury pools in that county underrepresented young people. In his article arguing that young adults should be a cognizable group for jury selection purposes, Donald Zeigler analyzed these data at length. See generally Zeigler, supra note 3. Professor Zeigler used the data to illustrate 
survey involving 579 participants revealed that income correlates more strongly than race, gender, age, or occupation with certain opinions that are particularly important to jury deliberations. ${ }^{294}$ The survey revealed that persons with low income were more likely than any other people surveyed to agree with the following statements: "District Attorneys sometimes conceal evidence from a grand jury in order to get an imdictment" and "Too often, the government brings people to trial who are not really guilty."295 Among the respondents who had previously served on petit juries, low income people were the most likely to agree with the opinion statements listed above and several others, mcluding: "It is better to let some guilty people go free rather than risk sendimg innocent people to jail."296 Among the survey participants who had previously served on a grand jury, income was the characteristic that correlated most strongly with views on nearly half of the opinion statements. ${ }^{297}$

Multiple regression analysis revealed that income correlated more strongly with juror opinions about criminal justice than did any other characteristic except age. ${ }^{298}$ In other words, mcome was a more important determinant of juror opinion than race, gender, or occupation. Thus, exclusion of the poor from jury selection may eliminate valuable perspectives about the crimmal justice system from deliberations. Such a loss undercuts the ability of juries to express accurately the judgment of the community, which is essential to the protection of litigants in the criminal justice system.

\section{Community Interests}

According to the Supreme Court, a second purpose of the fair crosssection doctrine is to preserve "public confidence in the fairness of the criminal justice system." 299 The Court has held that community participation in the jury process is vital to public acceptance of judicial outcomes. ${ }^{300}$ In short, juries "satisfy the community's desire to participate in, and conse-

\footnotetext{
"consistent and significant differences in attitudes among persons in different age groups on matters crucial to jury deliberations." Id. at 1077, 1078-1110. Although Professor Zeigler's article concerned young people, not the poor, his research also revealed a strong correlation between income, occupation, and juror attitudes "on matters of importance in jury service." Id. at 1094 n.211, 1084-95. These correlations were sufficiently strong that Professor Zeigler stated, in a footnote, that the data "support the additional conclusion that occupation and income groups are cognizable." Id. at 1093-94 n.211.

At least one study, however, found no significant relationship between jurors' family income and attitudes. See Reid Hastie, Steven D. Penrod \& Nancy Pennington, Inside the Jury 138-39 (1983). Yet, the same study revealed that "juror persuasiveness" was closely associated with income. Id. at 145.
}

294. Zeigler, supra note 3 , at 1077-78, 1088-90.

295. Id. at 1077-78 n.189, 1088-89.

296. Id.

297. Id. at 1090 .

298. Id. at 1091-95.

299. Taylor v. Louisiana, 419 U.S. 522,530 (1975).

300. Id 
quently to effect some control over, the criminal justice system."301 The Court has recognized that unrepresentative jury venires "create the appearance of bias in the decision of individual cases, and they increase the risk of actual bias as well.".302

Not surprisingly, empirical evidence suggests that members of some underrepresented groups have less confidence im the fairness of the jury system than do members of well-represented groups. For example, a nationwide poll conducted by the National Law Journal/Lexis of nearly 800 people who had served on civil and criminal juries revealed that black and white participants have fundamentally different views about the influence of race on jury verdicts, with blacks perceiving the system as heavily weighted against minorities. ${ }^{303}$ Two-thirds of the black respondents believed that minority criminal defendants receive unfair trials, while only one-third of the white participants agreed. ${ }^{304}$ Nearly seventy percent of the black jurors polled believed that the justice system is more likely to impose the death penalty unfairly on persons of color than on white defendants. ${ }^{305}$ In addition, more than sixty percent of the black respondents felt that white plaintiffs experience fairer treatment im civil trials than do minority plaintiffs. ${ }^{306}$ More than two-thirds of black jurors polled suggested that juries award more money to white plaintiffs than they award to black, Asian, or Latino plaintiffs for comparable injuries. ${ }^{307}$ Cominentators suggest that the reason black jurors believe minorities receive such unfair treatment "is that the [jury] system is run predominantly by whites." ${ }^{308}$ If that is so, this poll suggests a powerful correlation between the representativeness of jury venires and public confidence in the fairness of the justice system.

The Supreme Court has recognized that juries must be selected in a way that leads to their acceptance, not only by the participants in the system, but also by the community as a whole. As the National Law Journall Lexis poll indicates, groups that the jury selection process underrepresents are likely to view the jury system with skepticism and disapproval. Given that the poor constitute more than fifteen percent of the national population, their acceptance of the justice system is critical to its integrity. Improving the representation of lower incone people on jury venires is therefore crucial. ${ }^{309}$ Judicial recognition of the poor as a distinctive group would facili-

301. Massaro, supra note 256 , at 512 .

302. Peters v. Kiff, 407 U.S. 493, 503 (1972) (plurality opinion) (Marshall, J., joined by Douglas and Stewart, JJ.).

303. NAT'L L.J./Lexis Poll, supra note 282, at S8, S8-S9.

304. Id. at S8.

305. Id. at $\mathrm{S} 9$.

306. Id. at $\mathrm{S} 8$.

307. Id.

308. Id.

309. Although empirical data is not available, intuitively it seems that defendants would want juries to include their social and economic peers. For example, in the 1992 NAT'L L.J./Lexis survey of nearly 800 past jurors, $75 \%$ of the jurors polled said they would prefer to have their own legal disputes decided 
tate this process and would thereby advance the second purpose of the fair cross-section doctrine. ${ }^{310}$

\section{Democratic Interests}

The Supreme Court's third rationale for the fair cross-section doctrine is to promote shared responsibility for the administration of justice as a "phase of civic responsibility."311 The Court's fair cross-section jurisprudence overflows with rhetoric praising the jury as the quintessential democratic institution. For example, the Court has stated that juries drawn from a representative cross section of the community promote the interests of "democracy itself." 312 Commentators have offered at least three reasons why the jury is vital to democracy. First, juries educate citizens about democratic governance. Second, juries enable citizens to shape judicial outcomes to comport with the community's sense of justice. Third, jury service is a form of civic empowerment. Under each of these views, judi-

by a jury rather than by a judge. Most Jurors Would Want Their Own Case Decided by a Jury, Not a Judge, NAT'L L.J., Feb. 22, 1993, at S15. At least one commentator has interpreted this statistic as a "class-based answer." According to Magistrate Judge John L. Carroll, most jurors want a jury of their peers and are wary of judges because most judges are in higher social and economic strata than jurors. Id.

310. Some critics believe that judicial recognition of the poor as a distinctive group will actually erode existing public confidence in the fairness and legitimacy of the jury process. These critics suggest that juries already "represent[] the lowest common denominator of society" and lack competence for fair and rational decision-making. See Massaro, supra note 256, at 516-17 (summarizing criticisms of the jury system) (citations omitted). Although this criticism frequently comes from lawyers and academics, many laypeople also share this vicw. For example, nearly $60 \%$ of the respondents in a recent L.A. TIMES poll favored minimum educational requirements as a condition for jury eligibility. Josh Meyer, Small Vanguard Presses Its Case for Jury Reforms, L.A. TmEs, Sept. 28, 1994, at Al, A12. Such critics probably would not embrace the inclusion of the poor in jury venires.

However, the fact that some middle-class citizens may dislike the notion of serving on juries with the poor, distrust judgments made by jurors who are poor, or even question the efficacy of the jury system more generally, is irrelevant for purposes of the fair cross-section requirement. Massaro, supra note 256, at 517 (arguing that the debate concerning "[w]hether the jury is the best way to resolve the criminal cases . . . is irrelevant to decisions about proper jury composition and selection procedures").

The poor are an important group who constitute no less than $15 \%$ of the national population. The fair cross-section requirement aims to promote "public confidence in the faimess of the criminal justice system" by including identifiable groups in the jury selection process. Taylor v. Louisiana, 419 U.S. 522, 530-31 (1975). The founders intended the Sixth Amendment to provide a check against majoritarian oppression, not to enhance it. See generally Albert W. Alschuler \& Andrew G. Deiss, $A$ Brief History of the Criminal Jury in the United States, 61 U. CHI. L. REv. 867 (1994).

311. Lockhart v. McCree, 476 U.S. 162, $174-75$ (1986) (citing Taylor v. Louisiana, 419 U.S. 522 , 530-31 (1975)).

312. Glasser v. United States, 315 U.S. 60, 85-86 (1942); See also Fay v. New York, 332 U.S. 261, 299-300 (1946) (Murphy, J., dissenting):

[A] cross-section of the community includes persons with varying degrees of training and intelligence and with varying economic and social positions. Under our Constitution, the jury is not to be made the representative of the most intelligent, the most wealthy or the most successful, nor of the least intelligent, the least wealthy or the least successful. It is a democratic institution, representative of all quahified classes of people. (emphasis added).

Id. 
cial recognition of the poor as a distinctive group would enhance the democratic function of the jury.

First, Professor Phoebe Haddon suggests that jury service educates citizens about democratic governance. ${ }^{313}$ She argues that for many people, "jury duty may be their only experience with the law and government beyond the exercise of a local or federal vote."314 Jurors "converse and ... deliberate" with citizens who have different backgrounds and perspectives, which has "educational potential both in and beyond the particular trial.".315 As a result of the jury process, participants inay reflect on "alternative social experiences" and contribute to "normative understandings" among the jurors, judges, and lawyers. ${ }^{316}$ Therefore, the jury process can be "transformative" for all the participants. ${ }^{317}$ Under this view, the jury is the inodern day equivalent of the democratic town ineeting of nineteenthcentury New England.

The jury serves a second democratic function: providing community oversight of the justice system. Criminal and civil juries inake inportant decisions that affect litigants, and frequently nonlitigants, in profound ways. ${ }^{318}$ In addition, juries enjoy broad discretion. The legal standard for overturning a jury verdict is high, ${ }^{319}$ and successful challenges are rare. Moreover, because juries "are nameless, ever-changing bodies, they can make difficult, essentially subjective choices that would be less acceptable to the community if made by a single judge." ${ }^{320}$ An unrepresentative jury, however, cannot exercise discretion in a disinterested way and thus threatens the interests of disfavored minorities, such as the poor.

Some scholars believe that the jury gives citizens a vehicle to ensure that judicial outcoines comport with community notions of justice. According to this view, the jury provides a inechanism for popular change "short of revolutionary abolition and [the] institution of new legal systems." 321 Thus, Sanford and Mortimer Kadish have argued that the jury systein guarantees

313. Haddon, supra note 283 , at $56-61$.

314. Id. at $56-57$.

315. Id. at 62 .

316. Id.

317. Id. at 57.

318. For example, recall the Rodney King trial.

319. Cf. FED. R. Crv. P. 50(a)(1) and (b) (providing that a court may grant judgment notwithstanding the verdict only "[i]f during a trial by jury a party has been fully heard on an issue and there is no legally sufficient evidentiary basis for a reasonable jury to find for that party on that issue"); Lind v. Schenley Indus., Inc., 278 F.2d 79, 89 (3d Cir.) (noting that a court is not free to set aside a jury verdict merely because the court regards another result as more reasonable), cert. denied, 364 U.S. 835 (1960). If a trial court denies a motion for judgment notwithstanding the verdict, its decision is generally binding. Id. at 88 (noting that "appellate courts rarely find that the trial court abused its discretion").

320. Massaro, supra note 256 , at 513 . Of course, this responsibility may also be a source of public discomfort and distrust.

321. Kadish \& Kadish, supra note 266 , at 214. 
the freedom of [people] not simply subject to the law, but, always within limits, independent of the law and capable of using that law for the ultimate ends of the legal system. That consequence is itself a value, and brings in its train possibilities for adjustment to conditions that could not have been foreseen with any clarity and hence could not have been planned for in detail. ${ }^{322}$

In other words, juries may exercise limited—but legitimate-authority to nullify laws that offend the community's sense of justice, ${ }^{323}$ at least in the context of criminal acquittal. ${ }^{324}$ Of course, not all commentators einbrace this interpretation of the jury's role. ${ }^{325}$ However, if we accept that nullification is a legitimate role for juries, or at least accept that it will mevitably occur, it follows that jury venires should not underrepresent identifiable and substantial community groups such as the poor. Unrepresentative juries lack the authority to nullify unjust legal rules because they cannot speak on behalf of the entire community. Recognition of the poor as a distinctive group, on the other hand, would enhance the jury's legitimate authority to nullify laws that offend the community's sense of justice.

A third democratic feature of jury service is its capacity for civic empowerment. Although soine commentators take a less charitable view of the jury process, ${ }^{326}$ many agree with Professor Haddon that jurors perform an important civic function. Whether one views jury service as a privilege

322. Id. at 216.

323. See, e.g., Mortimer R. Kadish \& Sanford H. Kadish, Discretion to Disobey: A Study of Lawful Departures From Legal Rules 50-72 (1973) [hereinafter Discretion to Disobey] (describing the concept and conditions of legitimate interposition and the possibility of lawful rule departure by juries); Harry Kalven, JR. \& Hans Zeisel, The American Jury 312 (Midway Reprint ed., Univ. of Chicago Press 1986 (1966)) (stating that the jury, consistent with its historical role, "at times finds the penalty so disproportionate to its view of the offense that it is moved to acquit the defendant rather than subject him to that penalty"); W. Neil Brooks \& Anthony N. Doob, Justice and the Jury, 31(3) J. Soc. Issues 171, 171-73, 180-81 (1975) (arguing that jury nullification incorporates community notions of fairness into the criminal justice system).

324. Judge Leamed Hand observed that crimimal juries have the following special role:

I should like to subject a verdict, as narrowly as was practical, to a review which should make

it in fact, what we very elaborately pretend that it should be: a decision based upon the law. In criminal prosecutions there may be, and in my judgment there are, other considerations which intervene to make such an attempt undesirable.

Discretion to Disobey, supra note 323, at 53 (quoting United Statcs v. Spock, 416 F.2d 165, 182 (1st Cir. 1969) (quoting Skidmore v. Baltimore \& O. Ry., 167 F.2d 54, 70 (2d Cir.) (L. Hand, J., concurring), cert. denied, 335 U.S. 816 (1948))).

325. See, e.g., Gary J. Simson, Jury Nullification in the American System: A Skeptical View. 54 TEx. L. REv. 488 (1976) (arguing that jury nullification is unjustifiable).

326. For example, Professor Andrew Kull argues that jury duty "is commonly thought to be one of the burdens of citizenship, not one of its benefits." He also argues that jury service placcs "an unequal burden on black voters." Because blacks traditionally have been lcss likely to register to vote than whites, black voters who do register are more likely than white voters to have to appear for jury scrvice. For example, in DeKalb County, Georgia, a black voter is nearly $40 \%$ more likely to face jury duty than is a white voter. Kull argues that the "uneven incidence" of jury service "along racial lines appears to deny equal treatment to black voters-subjecting them, in effect, to a racially discriminatory tax on suffrage." Andrew Kull, The Slow Death of Colorblind Justice, AtLANTa Const., Nov. 29, 1992, at H1, H5. 
or a burden, the jury should be a broadly representative institution. Judicial recognition of the poor as a distinctive group would further this purpose.

Conversely, the exclusion of substantial groups froin jury pools can be a form of civic humiliation. The consistent underrepresentation in jury venires of identifiable segments of the population sends a message of social rejection. The appearance of judicial acquiescence compounds this stigma. ${ }^{327}$ As Professor Kuhn suggests, exclusion from the jury selection process seems to brand the excluded group as untrustworthy; "the law itself seems to assert their inferiority."328 If the poor "lack the qualities of intelligence and character necessary for jury service," why shouldn't society also distrust and disregard them as litigants, witnesses, and citizens? ${ }^{329}$ In other words, perpetual underrepresentation in the jury systein harms the poor, not inerely as potential litigants, but also as citizens. ${ }^{330}$ By failing to recognize the poor as a distinctive group in the jury context, the judicial system contributes to their marginal status in society.

A final function served by juries is what Jeffrey Abramson describes as "democratic deliberation."331 Professor Abramson argues that the jury is best-conceived as a "deliberative rather than a representative body." Abramson suggests that the jury's principal democratic virtue is that it forces citizens to engage in discussion and debate in order to achieve consensus:

Deliberation is a lost virtue in inodern democracies; only the jury still regularly calls upon ordinary citizens to engage each other in a face-to-face process of debate. No group can win that debate simply by outvoting others; under the traditional requirement of unanimity, power flows to arguments that persuade across group lines and speak to a justice common to persons drawn from different walks of life. By history and design, the jury is centrally about getting persons to bracket or transcend starting loyalties. This is why, ideally, voting is a secondary activity for jurors, deferred until persons can express a view of the evidence that is educated by how the evidence appears to others. ${ }^{333}$

327. See Brown, supra note 18, at 465-66 (arguing that if jury officials know that "a jury master list will be disproportionately white and non-poor if constructed from voter rolls, then it is hard to characterize the decision to use that source as impartial, and its adverse impact unintentional, with regard to race and class").

328. Kuhn, supra note 256 , at 247.

329. See id. at 248 (discussing the effects of excluding African Americans from jury service).

330. See id.

331. Abramson, supra note 289, at 9. For an insightful critique of Abramson's work, see generally

Robert P. Burns, The History and Theory of the American Jury, 83 CAI.I. L. REv. 477 (1995).

332. Id. at 8 .

333. Id. But see Robert P. Burns, The History and Theory of the American Jury, 83 CALIF. L. REv. 1477 (1995) (book review) (positing that "the jury should not engage in 'democratic deliberation' either by second-guessing the legislature's judgments regarding social expediency or even by engaging in 'moral deliberation' beyond a strict application of the [jury] instructions"). 
To summarize, jury service serves several democratic goals: education, civic empowerment, democratic deliberation, and community oversight. As an important deinocratic tool, the jury should be inclusive, rather than exclusive. To accomplish this goal, courts should consider whether representation of the group on jury venires would promote the purposes of the fair cross-section doctrine. These purposes include: (a) protecting the interests of individual litigants, especially criminal defendants, in obtaining unbiased trials; (b) promoting public confidence in the fairness of the jury system; and (c) ensuring that the jury functions as an organ of democratic governance.

\section{$\mathrm{V}$ \\ Practical Limits on Jury Service by the Poor}

The last Part argued that the poor are an identifiable group whose representation on jury venires would promote the interests of individual litigants, the community, and democratic government. Therefore, courts should recognize the poor as a distinctive group for purposes of the fair cross-section doctrine.

However, while judicial recognition of the poor's distinctiveness is valuable in itself, it may not alter the composition of federal juries. The

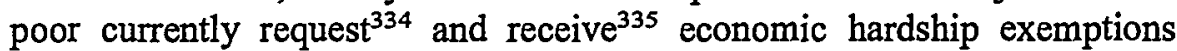
from jury service in disproportionate numbers. So long as this pattern continues, grand and petit juries are likely to renıain disproportionately middleclass, regardless of the coinposition of venires.

The fair cross-section doctrine does not guarantee criminal defendants a representative jury, only a representative venire. ${ }^{336}$ Because the doctrine prohibits systematic underrepresentation rather than voluntary selfexclusion, the solution to this problem lies $m$ the hands of Congress, not the courts.

\section{A. Economic Hardship Exclusion}

Empirical evidence demonstrates that federal courts routinely excuse people from jury service because of economic hardship. ${ }^{337}$ A study con-

334. Potential jurors may request removal from the venire if jury service would cause "undue hardship or extreme inconvenience." 28 U.S.C. $\$ 1866(c)(1)$.

335. See FuKURAI, supra note 19, at 120-23 (noting that potential jurors whose employers do not guarantee their salaries during jury duty are more likely to request economic hardship exemptions).

336. See, e.g., Lockhart v. McCree, 476 U.S. 162, 173 (1986) (holding that the fair cross-section reqnirement does not require petit juries to "reflect the composition of the community at large"); Taylor v. Louisiana, 419 U.S. 522, 538 (1975) ("[W]e impose no requirement that petit jưries actually chosen must ... reflect the various distinctive groups in the population."); Thiel v. Southern Pac. Co., 328 U.S. 217,220 (1946) (holding that the fair cross-section requirement "does not mean, of course, that every jury must contain representatives of all the economic, social, religious, racial, political, and geographical groups of the community; frequently such complete representation would be impossible").

337. See FuKURAI, supra note 19, at 120-23. 
ducted in Los Angeles County between 1983 and 1984 revealed that economic hardship was "the single most significant form of voluntary selfexclusion" from jury service. ${ }^{338}$ Nearly three quarters (73\%) of the 360,000 people who requested to be excused from jury service claimed economic hardship..$^{339}$ Given the inadequate compensation of jurors in most districts, this result is not surprising. ${ }^{340}$ A person surviving on mimimum wage sinply cannot afford to take an involuntary pay cut for several weeks. ${ }^{341}$ The economic sacrifice entailed by jury service creates what Professor Kuhn states may be the "most serious source of bias against the poor in the jury system: the economics of jury service."342

The economic barriers to jury service may present an obstacle to the achievement of representative juries that is more difficult to overcome than the doctrinal hurdles discussed above. Thus, if Congress is concerned about the representativeness of actual juries-as opposed to merely jury venires-jury reform is of paramount inportance. Unless Congress increases the compensation for federal jurors and provides child care facilities, economic hardship will continue to perpetuate the systemic bias against the poor.

\section{B. Expense}

If Congress takes the fair cross-section guarantee seriously, it should allocate the necessary fees and services to enable the poor to serve on juries. ${ }^{343}$ The obvious problem, of course, is that meaningful jury reform is expensive. For example, the New York legislature is currently considering an ambitious jury reform package, including a proposal to mcrease daily juror fees from fifteen dollars to forty dollars. ${ }^{344}$ The estimated annual cost of this fee increase is $\$ 9.8$ million. ${ }^{345}$ Federal reform obviously would cost much more. Yet, given the current political climate, even inodest reform seeins unlikely. In fact, federal courts are already perpetually underfunded. For example, in June of 1993, federal judges threatened a system-wide shutdown of the civil jury system because Congress had not appropriated sufficient funds to cover juror fees. ${ }^{346}$ To say the least, jury reform appears low on the list of Congressional priorities.

338. Id. at 120.

339. Id. at 121. Compounding this problem, some potential jurors request exemptions because they lack child care or transportation. Id. at 119.

340. Id. at 139 (reporting that "in 1991, although jury fees vary among counties, jurors were awarded $\$ 5$ a day in most state and federal courts in Califormia").

341. See id. at 120; Kuhn, supra note 256, at 322.

342. Kuhn, supra note 256 , at 322.

343. See id. at 323.

344. Gary Spencer, Far-Ranging Jury System Changes Adopted, N.Y.L.J., Oct. 25, 1994, at 1, 1-2. 345. Id.

346. Aaron J. Broder, Closing the Federal Courts, N.Y.L.J., June 30, 1993, at 3; Stephen Labaton, Federal Judge Blames Money Woes for Slowdown, N.Y. Tmes, Apr. 9, 1993, at B-16. 
Political realities aside, one might question whether a society concerned about the poor should spend its limited resources on improving the representativeness of jury pools when it could use the same funds to provide more fundamental services, such as housing, job training, or other entitlements to poor people. This inquiry misses the poimt. The interests of potential jurors are not the only ones that are judicially cognizable. ${ }^{347}$ The jury must also serve the interests of defendants, the community, and democratic government. ${ }^{348}$ Thus, jury reform is not an entitlement program. It is an issue of constitutional policy.

\section{Easing Judicial Reluctance}

Even if we assume that substantive jury reform is unlikely to occur anytime soon, federal courts should rethink their distinctiveness jurisprudence. Although doctrinal change alone probably will not alter the composition of federal juries, clarity and consistency in legal doctrine are worthy goals in themselves. Yet doctrinal change confronts its own obstaclejudicial reluctance.

One source of judicial reluctance might be simple misunderstanding: a conflation of the notions of a distinctive group under the Sixth Amendment and a suspect class under the Fourteenth Amendment. ${ }^{349}$ Because courts have linked distinctiveness to the Fourteenth Amendment's focus on societal discrimination, a finding that the poor are distinctive requires a finding that American society has discriminated against poor people. This recognition would challenge some central notions about our economic and political structure; as a society we would have to rethink the "rhetoric of poverty."350 This would be an uncomfortable task even for a courageous court; economic mobility is at the core of the "American Dream." 351 The current doctrine thus inhibits its own development. Until courts devise a clear doc-

347. See Rabinowitz v. United States, 366 F.2d 34, 59-60 (5th Cir. 1966) (en banc) (stating that when a venire is underrepresentative, "[t]he injury is not limited to the defendant-there is injury to the jury system, to the law as an institution, to the community at large, and to the democratic ideal reflected in the processes of our courts" (citations omitted)).

348. See Massaro, supra note 256, at 511 (stating that "[t]he several interests the jury is said to protect are essentially defendant-centered, community-centered, and government-centered").

349. See Zeigler, supra note 3, at 1064 (stating that "to date, courts have treated cognizability in much the same manner in sixth amendment and equal protection cases'); supra notes 242-246 and accompanying text. Perhaps the courts' confusion is understandable, given that the cross-section doctrine developed in fits and starts from three distinct constitutional sources and from a vaguely worded federal statute. See Zeigler, supra note 3, at 1064 (arguing that the cross-section right has several sources, including the Sixth Amendment, the Equal Protection Clause of the Fourteenth Amendment, the Supreme Court's supervisory power over federal courts, and the JSSA).

350. See generally Ross, supra note 191 .

351. At the very least, judicial recognition of this discrimination against the poor would discredit the comforting notion that Adam Smith's "invisible hand" rewards those who are hard working, innovative, intelligent, and independent. Market failure is generally not part of the popular rhetoric. Instead, poverty is often blamed on sloth, immorality, and stupidity. Ironically, market failure is raised most frequently to point out that the welfare state creates perverse incentives enabling the poor to flourish without working. See PosNer, supra note 189, at 441-44. Under this view, the poor are 
trinal line between a distinctive group and a suspect class, courts will reinain reluctant to take judicial notice of the poor in the context of the fair cross-section doctrine.

Stare decisis provides a second reason courts may be reluctant to abandon the current test for distinctiveness. In the past, several courts have held that the poor are not cognizable for jury selection purposes. ${ }^{352}$ Of course, courts must be sensitive to precedent. However, judicial restraint sometines helps to perpetuate serious misapplications of the law. This is such a case. Since the early 1980s, few defendants have brought fair cross-section challenges based on the distinctiveness of the poor, presumably because the task seeins futile. Legal development in this area has chilled.

A third reason courts nay be reluctant to abandon the present test is for fear of inviting judicial discretion. The methodology proposed in this Comment does not eliminate all potential for judicial abuse. Nor should it. Evaluating the distinctiveness of a social group is a difficult task that requires judges to exercise discretion. Any judicial inquiry about attitudes and perspectives is necessarily subjective. Although judges should not wield unfettered discretion, an overly restrictive definition of distinctiveness hurts more than it helps. Constructing a high, and decontextual, doctrinal hurdle perpetuates the underrepresentation on jury venires of some groups that are essential to the legitimacy of the jury systein, such as the poor.

The doctrinal test proposed in Part IV offers a different approach. ${ }^{353}$ Courts should focus their inquiry on whether judicial recognition of the group would enhance the jury process, rather than considering whether meinbers of the group in question face discrimmation outside the jury context. This methodology links the doctrinal inquiry to the fundamental purpose of the fair cross-section doctrine: ensuring adequate representation of groups with novel perspectives on issues of critical importance to the jury process. Although this test is somewhat subjective, it lends itself to objective measurenent-through sociological evidence-in ways that the current inquiry about societal discrimination does not. This approach should address both sources of judicial reluctance discussed above. First, the proposed methodology does not put courts in the position of "overturning the

characterized as rational economic actors who seek to maximize their personal utility by consuming leisure. Id.

352. See supra Part II.E.

353. Although this proposal may create problems associated with overly broad judicial discretion, Professor Zeigler offers a doctrinal solution. He argues that the risk of judicial misconduct "does not justify a narrow interpretation of cognizability." Zeigler, supra note 3, at 1062. Zeigler claims instead that courts could more effectively minimize the potential for judicial abuse "by requiring that a greater [statistical] disparity be shown to establish a prima facie case or by easing the defendant's burden on rebuttal." Id. Under this proposal, courts would shift their focus from a subjective inquiry about the group's distinctiveness to an objective analysis of statistical disparity. This approach would enable underrepresented groups to challenge their exclusion from jury venires, yet it would constrain judicial discretion. 
apple cart." As a matter of political reality, it is far easier for courts to recognize that the poor have distinctive qualities that make their presence essential to the fairness of juries than to hold that the poor are victims of general societal discrimination. Second, this test is faithful to precedent, drawing on the fundamental purposes of the fair cross-section doctrine as identified by the Supreme Court.

\section{CONCLUSION}

Judges currently lack a principled basis for determiming whether a particular group is distinctive for purposes of jury selection. Under the current doctrine, judges are supposed to evaluate a series of ill-defined factors that do not provide a supportable distinction between groups recognized as distinctive and other societal groups. This doctrine lacks predictive value and cogency, and most judges appear to disregard it. As a result, courts have developed alternative approaches for defining distinctive groups. Some judges cling to an artificial distinction between "binary" and "non-binary" characteristics. The result has been a series of inconsistent judicial conclusions that collapse under critical scrutiny. Other courts apply a single inquiry: whether the group is a suspect class. This approach conflates two distinct doctrinal questions, blurs the distinction between the Sixth and Fourteenth Amendments, and reaches unjustifiable results.

Courts need a new methodology. They should disregard whether members of a group face discrimination outside the jury context and consider whether judicial recognition of the group would enhance the jury process. Increased representation of the poor in jury venires would promote the interests of individual litigants, increase public confidence in the fairness of the jury system, and enable the jury to serve as an organ of democratic governance. Therefore, courts should recognize the poor as a distinctive group for purposes of jury selection.

Of course, even if the courts were to recognize the poor as a distinctive group, there is no guarantee that federal juries would become more representative. So long as the poor and other underrepresented groups seek hardship exemptions from federal jury service in disproportionate numbers, juries will not reflect all the relevant groups in the community that are critical to the legitinacy of the jury process.

Therefore, substantive jury reform inust accompany doctrinal change. Such reform will not be painless. Jury reform requires inoney, political will, and critical thought. Nonetheless, the underrepresentation of poor people and other distinctive groups on juries undermines the legitinacy of our democratic constitutionalism. Until the courts and Congress devise a mechanism to ensure that the jury process imcludes each of the distinctive components of the community, the fair cross-section guarantee will remain an empty promise. 